\title{
Craft Documentation of Flexible Brass Craft of Bellaguntha, Ganjam, Odisha, India
}

\author{
Santosh Kumar Jha \\ School of Leather Goods \& Accessories Design, Footwear Design \& Development \\ Institute, Noida. \\ Email: handicraftdesigner@gmail.com
}

Received September 15, 2016; Revised October 15, 2016; Accepted October 20, 2016; Published October 22, 2016

\begin{abstract}
Documentation of a traditional craft is important for preserving its identity and to communicate its details to the audience. So, this was important to document different aspects of the flexible brass craft of Bellaguntha. This paper is based over a set of field visits to these craft clusters, located in and around Bellaguntha block area in Ganjam district of Odisha state in India, by this researcher. The purpose of this paper is to prepare a literature database about the flexible brass craft of Bellaguntha, which may help for further research activities by encouraging researchers, who are willing to contribute in the areas of craft studies, traditional knowledge, conservation and preservation of indigenous technologies, design research etc. not only in India, but also in other developing and underdeveloped nations of our beautiful world; where a number of countless traditional crafts and indigenous knowledges are still under waiting and attracting researchers to explore further studies, documentation and publication, so that their glorified existence can be recognized by the world community.
\end{abstract}

Keywords: Craft and Design Studies, Languishing Traditional Metal Craft, Handicraft Artisan, Craft Studies, Conservation of Indigenous Technical Knowledge, Craft Documentation

\section{Introduction}

Biomimicry ${ }^{1}$ always attracted human being and creative thinkers, due to its cognitive approach over human mind, as it is an essential part of our ecology. The flexible brass craft of Bellaguntha is among world's pioneer biomimetic representation ${ }^{2}$ through craft, which is still surviving today and able to produce and explore different aquatic-biomimetic ${ }^{3}$ forms, by maintaining its visual and physical biomimetic approach ${ }^{4}$. Brass is the basic material for this craft and is an example of highly skilled metal craft. Primarily end products of this craft can be categorized as the decorative products. Every individual end product of this craft carries visual and physical appeals of biomimetic life, through its flexible quality and dancing nature, which is achieved through skillful craftsmanship in Bellaguntha area. Bellaguntha is a block headquarters, under the Ganjam district

${ }^{1}$ (The Biomimicry Institute, 2008-2016)

${ }^{2}$ (Moharana, 2015)

3 (M. Sfakiotakis, 1999)

${ }^{4}$ (Benyus, 2002)

(C) AesthetixMS 2016. This Open Access article is published under a Creative Commons Attribution Non-Commercial 4.0 International License (http://creativecommons.org/licenses/by-nc/4.o/), which permits non-commercial re-use, distribution, and reproduction in any medium, provided the original work is properly cited. For citation use the DOI. For commercial re-use, please contact editor@chitrolekha.com. 
of Odisha state. Odisha is geographically situated alongside the Bay of Bengal, in central-eastern India.

\section{Purpose of Study}

The purpose of this study is to prepare a basic craft document for the flexible brass craft of Bellaguntha, which is based over different field visits, interactions with crafts persons and other interlinked stalk holders, associated with this craft cluster, by this researcher.

\section{Methodology}

This study is based over primary and secondary data sources and supplemented by tertiary sources of data. Primary data collected through different set of personal interactions, meetings, and observations done by this researcher and study of few old documents available with craftsmen, in their personal files. As at present a number of around to highly skilled artisans are involved on full time basis, in craftsmanship; while around 20 other trained and semi-skilled artisans are also involved on a part time basis along with their involvements in other occupationsso, almost all of them were contacted; among other stalk holders- 04 local craft byers, 02 bank officials, o1 librarian, and o1 local temple priest were also contacted for data collection purposes. Further, for supporting the set of received information, tertiary data sources had also been accessed through online electronic media, whether required.

However this researcher had tried to put correct information in this document at his level best. But, the information compiled in this document may vary considerably due to unforeseen circumstances- as the opinion about the same issue could differ person to parson, so some vital observational differences could be possible, which can't be ignored. Therefore, this researcher cannot warrant, express or imply-concerning the accuracy of the information presented and will not be liable for any injury claims pertaining to the use of this document or the information contained therein.

\section{Geography and Location}

As per the readings found through, online Global Positioning System ${ }^{5}$ enabled tool- MAPSzoom ${ }^{6}$, with its result precision rate of \pm 5 meters, the geographic location of Bellaguntha was identified at the Latitude of $19.883^{\circ}$ North and at the Longitude of $84.636^{\circ}$ East location over the Decimal Degree $^{7}$ scale. According to readings received through, Global Positioning System based, satellite supported, application tool ${ }^{8}$, “Above Mean Sea Level”, Bellaguntha's average geographic land level is approximately 70.923 meters high from the existing sea level. The average temperature of June' 2015, month's average temperature was $97^{\circ}$ Fahrenheit or $36.12^{\circ}$ Celsius ${ }^{9}$, while, the average temperature in December' 2015, was $83^{\circ}$ Fahrenheit $^{10}$ or $28.34^{\circ}$ Celsius $^{11,12}$.

\footnotetext{
5 (Cooksey, 2016)

${ }^{6}$ (MAPSzoom, 2015)

7 (Davis, 1999, p. 40)

8 (FreeMapsTool)

9 (AccuWeather, 2015-2016)

${ }^{10}$ (Rouse, 2005)
} 
Bellaguntha is a notified block area, with an area council. Bellaguntha comes under the Bhanjanagar sub-division of Ganjam district in Odisha state. The Odisha state is situated in the east-central part of India. This block surrounded by the Bhanjnagar and Jagannath Prasad blocks in north direction; in south direction, it is surrounded by the Dharakote and Aska blocks; the Buguda block is situated in east direction; while the Surade block in situated in west direction.

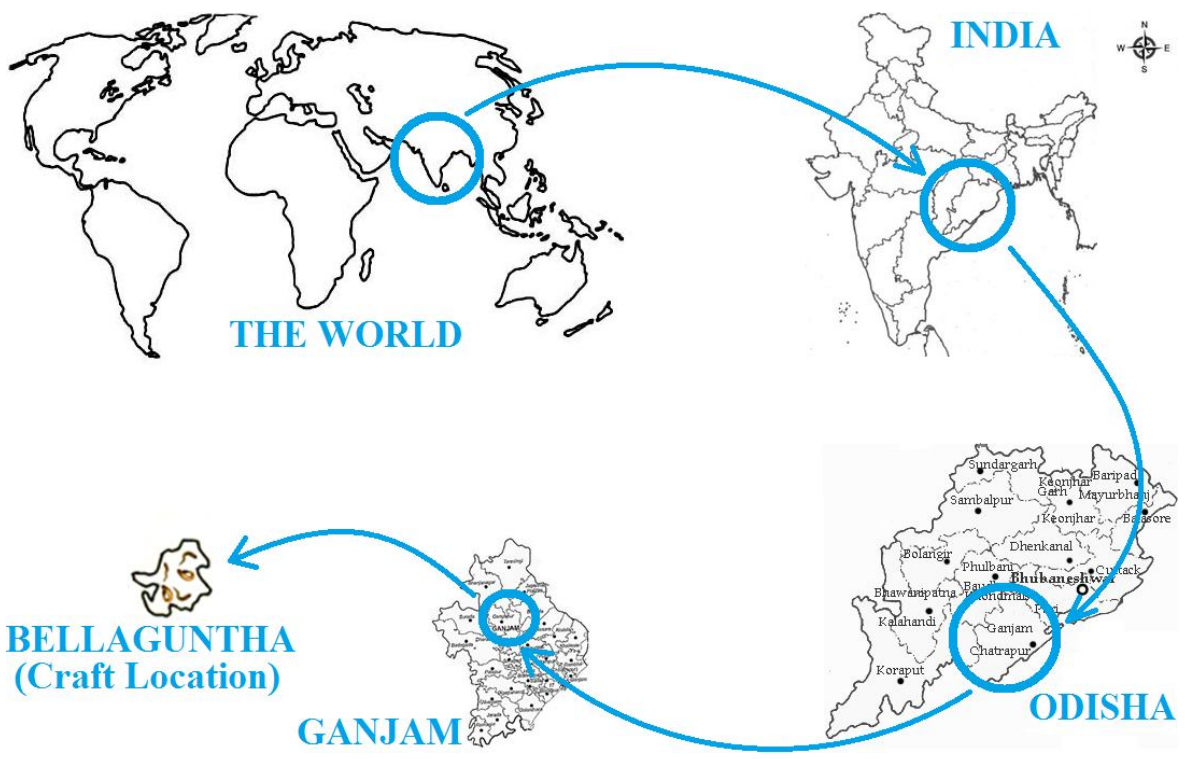

Figure-1: The geographic identification of flexible brass craft cluster on a world map (Illustrated by author)

\section{How to Reach Bellaguntha}

Bhubaneswar is directly connected by Air from New Delhi, Kolkata, and Bangalore etc. like internationally airways linked metropolitan cities in India. Bellaguntha is around $160 \mathrm{Km}$ away in southern direction from the Orissa State capital Bhubaneswar. Local bus services are available from the state capital Bhubaneswar, from its Baromunda bus stop.

The allotted Subscriber Trunk Dialing Code or telephonic identification code for the telephonic land line communication from this area is "o6821" by the Bharat Sanchar Nigam Limited" and the Postal Index Number or PIN Code, " 761119 " is allocated to the Bellaguntha ${ }^{14}$ block.

\section{Distribution of Craft Clusters}

The habitat of flexible brass craft artisans is distributed at 07 different locations under Bellaguntha block area, of which 02 clusters are active at large and regularly producing flexible brass products. While, other craft pockets are not actively participating in craft activities these days due to different issues, like- migration of artisans, mirage of artisans or due to poor income, artisans had shifted their profession. Geographically, Bellaguntha is situated in the center of the map and is well connected by the road transport from all of the craft clusters.

" (Encyclopædia Britannica, Inc., 2016)

${ }_{12}^{12}$ (AccuWeather, 2015-2016)

${ }^{13}$ (Bharat Sanchar Nigam Limited, 2014)

${ }^{14}$ (India Post, 2016) 


\subsection{Active Clusters}

\subsubsection{Bellaguntha Cluster}

This craft cluster in located in Bellaguntha itself and is approachable through walk only. This cluster is larger in human resource and considered as the pioneer cluster. The monthly production capacity of this cluster is approximately 100 to 150 units of ready to market flexible brass products with form diversity. The cluster produces flexible brass lobsters, snakes, fishes and other forms on specific demands by customers. This cluster has its own showrooms near Bellaguntha bus stand. The Bellaguntha craft cluster is mostly practiced by "Moharana" or "Maharana" community of brass smith artisans, who are direct descendants of Sri Harikrishna Moharana.

\subsubsection{K-Noagad Cluster}

The K-Noagad is a village, which is situated under the Bellaguntha Block. This cluster is approachable from Bellaguntha bus stand by auto rickshaw or through locally available other mode of transports. The monthly production capacity of this cluster is approximately 100 units of ready to market flexible brass fishes and other flexible forms. This cluster forwards its end products to the showrooms available in Bellaguntha and other locations. The K-Noagad craft cluster is mostly practiced by "Sahoo" community of brass smith artisans, who are direct descendants of Sri Harikrishna Moharana's Sister, who was married in K-Noagad's Sahoo family.

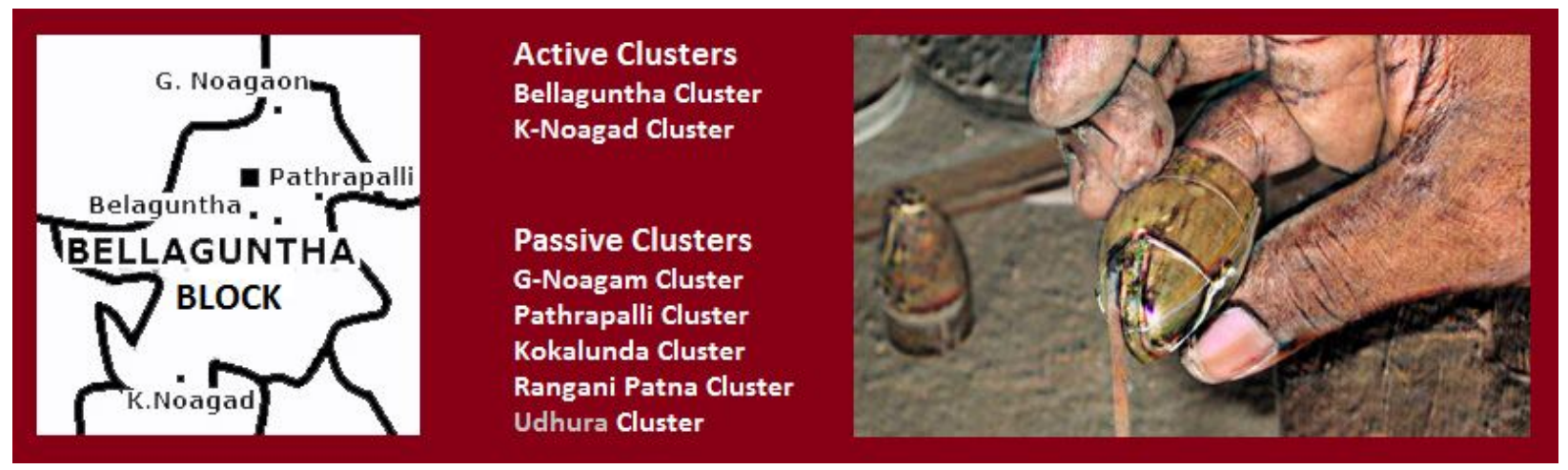

Figure-2: Flexible brass craft clusters in Bellaguntha area (Photography, Sketch and Illustration by Author) (Map: Not to be scaled)

\subsection{Passive Clusters}

There are 05 more flexible brass clusters are available in Bellaguntha block area, named as: GNoagam craft cluster, Pathrapalli craft cluster, Kokalunda craft cluster, Rangani Patna craft cluster and Udhura craft cluster. These clusters are reachable through local auto rickshaw, trolley, mini bus etc. like several modes of transportation, which is available from the Bellaguntha bus stand, during early morning till late evening. But almost, all of these clusters are now under passive professional mode and are hardly functional and are unable in actively contributing to the craft activities at present, due to different sustenance related factors. 
Among others, some of the dominating factors are migration of artisans to different metropolitan and other cities in search of better livelihood opportunities and professional trade shift due to poor income from craft practices, while in other factors, mirage of unmarried female artisans, had been observed. Even among active artisans, a common trait was seen; these artisans have now partially or completely shifted their profession to full-fill their daily bread and butter requirements. Although, artisans of these clusters are supporting the craft activities undertaken by active cluster members in Bellaguntha or K-Noagad. Most of the artisans, belonging to these 05 craft clusters were trained by master craftsmen of Bellaguntha or K-Noagad.

\section{History of Craft}

\subsection{Origin of Craft}

The prefect date or era about origin of this craft is unknown. However, a couple of available documents ${ }^{15,16,17}$ had reported, that this craft came in existence during the regime of Bhanja Kings in $09^{\text {th }}$ century $\mathrm{AD}$. But, these documents are unable to provide any authentic evidence against their claim.

During any oldest and available original document search, this researcher came across with an engraved "๑/gه-घG", or Tambra Patra, or Copper Plate issued by the then King His Highness Maharaja Krishna Chandra Bhanja Deo of Mayurbhanja Kingdom, which was later known as Mayurbhanj Princely State ${ }^{18}$ - during British India ${ }^{19}$; in the form of Certificate of Appreciation to honor the craftsmanship excellence of the then veteran craftsperson of Flexible Brass Craft, Sri Bhikari Moharana. Along with different details of awarded property and other benefit details, this royal Tambra Patra also carries a date of issue, i.e., Magha, Sukla Panchmi (here, Magha is the month and Sukla Panchmi is the day of such month)- represents a date in traditional Hindu Calendar $^{20}$, which comes every year. But as the script used for writing is quite classic, and different from today's form of Odiya language, so, the learned translating artisan community member was unable to understand the year of issue, engraved over the Tambra Patra.

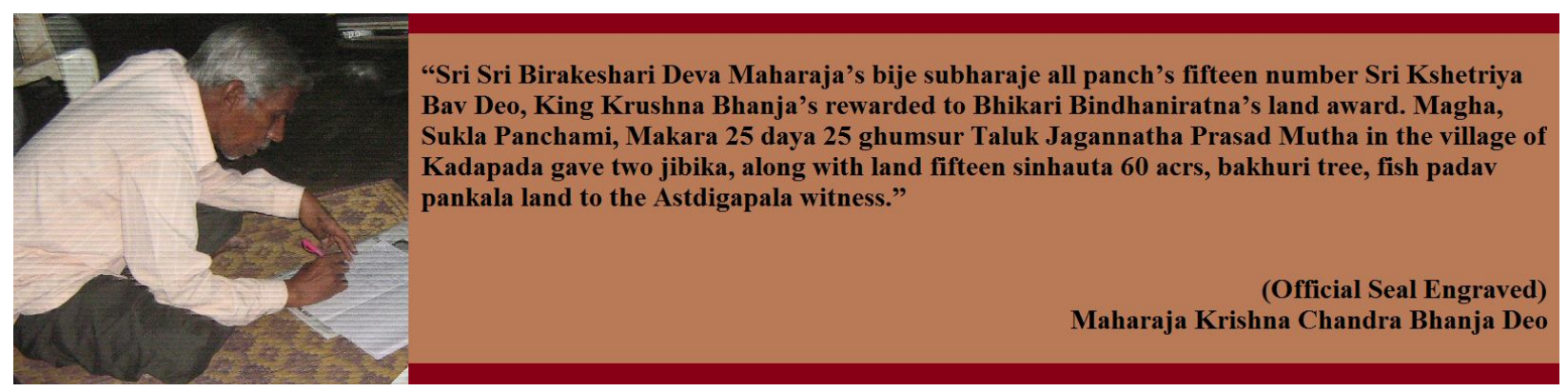

Figure-3: The original Tambra Patra is written in classis Odiya script. English translation was provided by a learned flexible brass craft community member (Photography and Illustration by Author)

15 (Sahu, 2015)

16 (SocialPedia: WikiPedia of Social Issues, 2016)

${ }_{17}$ (Blogarama.com, 2015)

18 (Awesome Inc., 2014)

19 (Mill, 2010)

${ }^{20}$ (VedicTime.com, 2012-2016) 
However, the time line of this Tambra Patra can be established through referencing. So, this researcher tried to find out the time-line of His Highness Maharaja Krishna Chandra Bhanja Deo, but it was also not available. During literature survey, this researcher was able to find a strong reference point, and came to know that His Highness Maharaja Krishna Chandra Bhanja Deo fought a war, against the then Mughal Emperor of Mughal Empire ${ }^{21}$, His Highness Abu'l Muzaffar Muhi-ud-Din Muhammad Aurangzeb Alamgir, who is also known as Aurangzeb ${ }^{22}$. As existing documents are providing a clear time-line for Mughal Emperor His Highness Aurangzeb as, 1658 $\mathrm{AD}$ to $1707 \mathrm{AD}^{23}$, so, this time-line may be established for the purpose of establishing the time-line of above mentioned Tambra Patra issued by His Highness Maharaja Krishna Chandra Bhanja Deo of Mayurbhanja Kingdom, to Sri Bhikari Moharana.

On the basis of above set of literature findings and further discussions- this might possible, that the flexible brass craft came in existence in the era of the then Bhanja dynasty in $09^{\text {th }}$ century, in Bellaguntha area; but received first professional recognition during 1658 AD to 1707 AD. So, Sri Bhikari Moharana may consider as the first known conceptualizer and prototype creator in this craft, under the horizon of evidence-based-history ${ }^{24}$. According to this Tambra Patra, Sri Bhikari Moharana was also given a title of honor by the then king, as "Bindhaniratna".

Sri Bhikari Moharana of Bellaguntha, was awarded by the then king, His Highness Maharaja Krushna Chandra Bhanja, for his excellent craftsmanship, with biomimetic approach, and successful public demonstration of Flexible Brass products, which is supported by the above Tambra Patra award, which was issued by the King His Highness Maharaja Krishna Chandra Bhanja Deo, on engraved copper plate, with his official seal during 1658 AD to 1707 AD. This is the first available and recognized written evidence, preserved by the craft community members.

Further he trained his children about different craft techniques and methodologies, by sharing his inherited knowledge database. Further, this became his family's knowledge-shift tradition. Sri Bhikari Moharana's present generation is still carrying forward their hereditarily earned legacy of craftsmanship, in different locations, within Bellaguntha area.

\subsection{Craft History After Sri Bhikari Moharana}

As per the present generation descendants of Sri Bhikari Moharana and their ancestors were under employment, as skillful resources, in the Royal Armory of the then King, where they were developing different war jackets, arms and ammunitions etc. for the then king's Royal Army. Later, they had started exploring craft possibilities, by using similar basic armory techniques, to bring some fun element in his anonymous life. So, basically Sri Bhikari Moharana had diversified his existing technical skills by exploring aquatic creature forms. End products were full of biomimetic fun elements, so the pool of the then audience appreciated his explorations. This was the beginning of this glorified craft, which is today known as the flexible brass craft of Bellaguntha.

Further, during the British Raj era in Indian subcontinents, this craft was well supported by the then British Government through its own art and craft promotion agency. This institution was established in $1887 \mathrm{AD}$ at Madras; which is known as Chennai these days. This charitable institution was established to market and promote Indian crafts and arts, and was named after

${ }^{21}$ (Chandra, Medieval India: From Sultanat to the Mughals- Mughal Empire (1526-1748), 2007)

${ }^{22}$ (Government of Odisha, 2009)

23 (National Council Of Educational Research And Training-NCERT, 2015)

${ }^{24}$ (Suman, 2015) 
the then British Queen, Her Majesty Empress Victoria ${ }^{25}$, and further known as, the Victoria Technical Institute ${ }^{26}$. A letter containing professional communication, addressed to Sri Narasinga Moharana (the then descendent of Sri Bhikari Moharana) from the Victoria Technical Institute, dated 07.06.1946 and duly postal stamped on 09.07.1946 on 04:30pm in Bellaguntha Post Office (please refer figure-6 below).

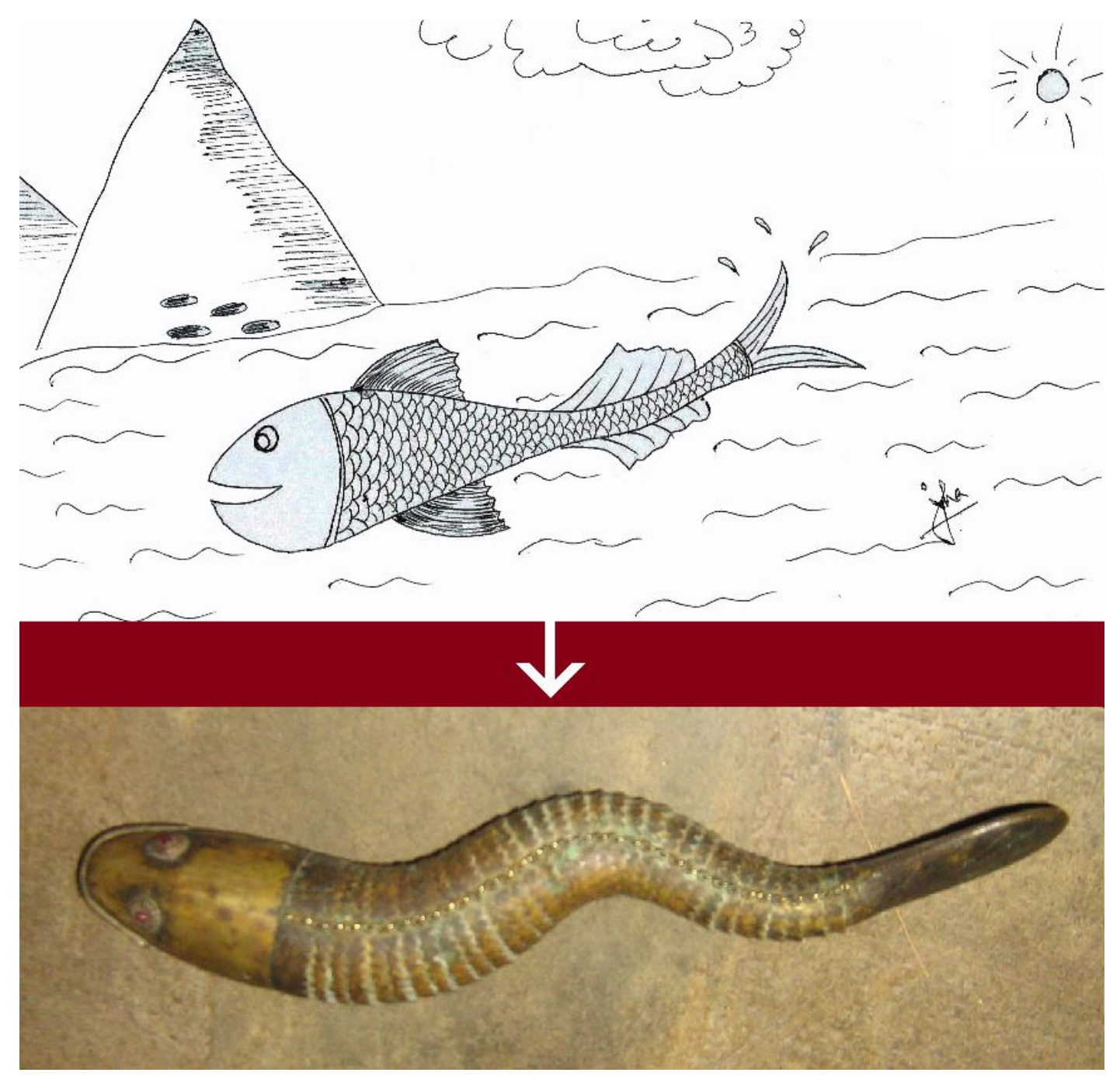

Figure-4: Swimming Fish inspired, Biomimetic craft-expression, through Flexible Brass Craft (Photography, Sketch and Illustration by Author)

In their next generation, Sri Harikrishna Moharana was awarded by the then President of India, His Highness Sri Varahagiri Venkata Giri, while his younger brother Sri Anant Moharana was honored by the Victoria Technical Institute, Madras. His eldest son Sri Pradeep Moharana and his two brothers are still alive and actively involved in this craft, with their craftsmanship excellence along with other community members. Sri Pradeep Moharana received the State Government Award in $2000 \mathrm{AD}$, offered by the state Government of Odisha for his craft excellence. This craft

\footnotetext{
${ }^{25}$ (Williams, 2016)

${ }^{26}$ (Victoria Technical Institute, 1887)
} 
family is the only direct ancestral family, which is associated with this craft, these days. However their maternal extensions are also under regular craft practices in K-Noagad village, which is situated under the same Bellaguntha block area and in leading by the descendants of Sri Bharat Sahoo, these days.

\subsection{Knowledge Shifts}

\subsubsection{Knowledge Shift-I}

As per the voices of leading craftsperson in Bellaguntha, the then British Governor of Madras Presidency was highly impressed with the works of Sri Gangadhar Moharana- the descendent of Sri Bhikari Moharana. So, one day, he called and instructed Sri Gangadhar Moharana to train his craft techniques to a group of British metal crafters. Sri Gangadhar Moharana was not convinced and morally disagreed with the then British Governor's orders to disclose this descended occupational knowledge through this training drive. But, as the then Bellaguntha region was ruled by the then British Empire, so, he was unable to express his disagreements with him. Now, he felt under fear generated depression, due to his deep attachment with his descended craft skills. As he was responsible for craft flag bearing for his generation, so he thought that through the Governor's proposed knowledge and craft sharing drive, his heritage secretes may be misused and mislead by the British learners and afterwards he will be unable to stop such uncontrolled practices by them (if any). In another way, he found that by following Governor's orders, there were sufficient chances that his craft-family would have to lose the monopoly from their own heritage craft. So, finally due to this psychological fear factor, he decided to commit suicide in 1883 AD, when he hanged himself in a black night. This was the worst phase, witnessed by this craft in its history, and was created a pause for this craft. ${ }^{27}$
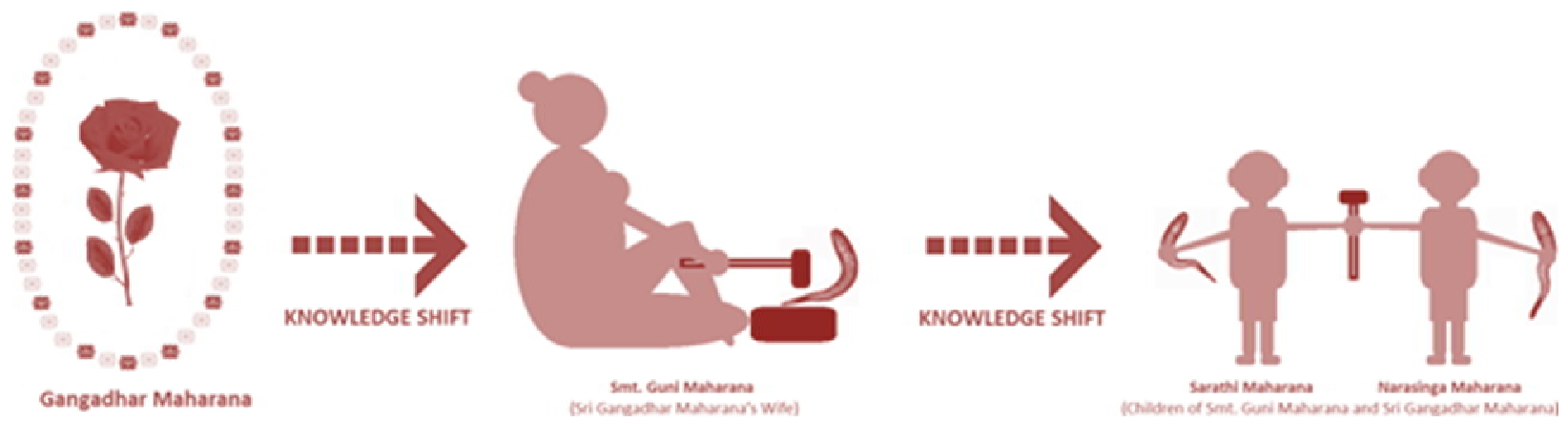

Figure-5: Life threat to Sri Gangadhar Moharana and knowledge shift by Smt. Guni Moharana to her children Sri Sarathi Moharana and Sri Narshinga Moharana (Information Source: Descendant Sri Pradeep Kumar Moharana, Illustration by Author)

Now, Sri Gangadhar Moharana's widow, Smt. Guni Moharana had taken charge of her family's craft tradition. Even she was facing such a hard time, she had trained her o2 children- Sri Sarathi Moharana and Sri Narasinga Moharana, please refer figure-5 above. On the basis of craft learning received under active guidance and supervision from their beloved mother, Smt. Guni Moharana's both children, explored the dimensions of this craft and enriched their hereditary craft traditions. Further, these brother duos had established an organization, i.e., the Bellaguntha Biswakarma Cooperative Society in Bellaguntha and bear the craft flagship. Sri Narasinga Moharana,

${ }^{27}$ (Moharana, History of Flexible Brass Craft of Bellaguntha, 2015) 
reestablished a professional relationship with the ten British Government and created a regular trade alliance with the Victoria Technical Institute, please refer figure- 6 below .

Although, flexible brass artisan community of Bellaguntha is following the male leading family structure, but Smt. Guni Moharana established the fact, that a lady with strong willpower can also lead, nourish and maintain her family traditions alone. Alone, she survived the flexible brass craft to die, after the sudden and unexpected demise of the then craft-master, Sri Gangadhar Moharana. Due to her strong contributions, she is highly respected among the flexible brass craft artisans in Bellaguntha. Her third generation is now a day practicing this incredible craft, by applying her lessons.
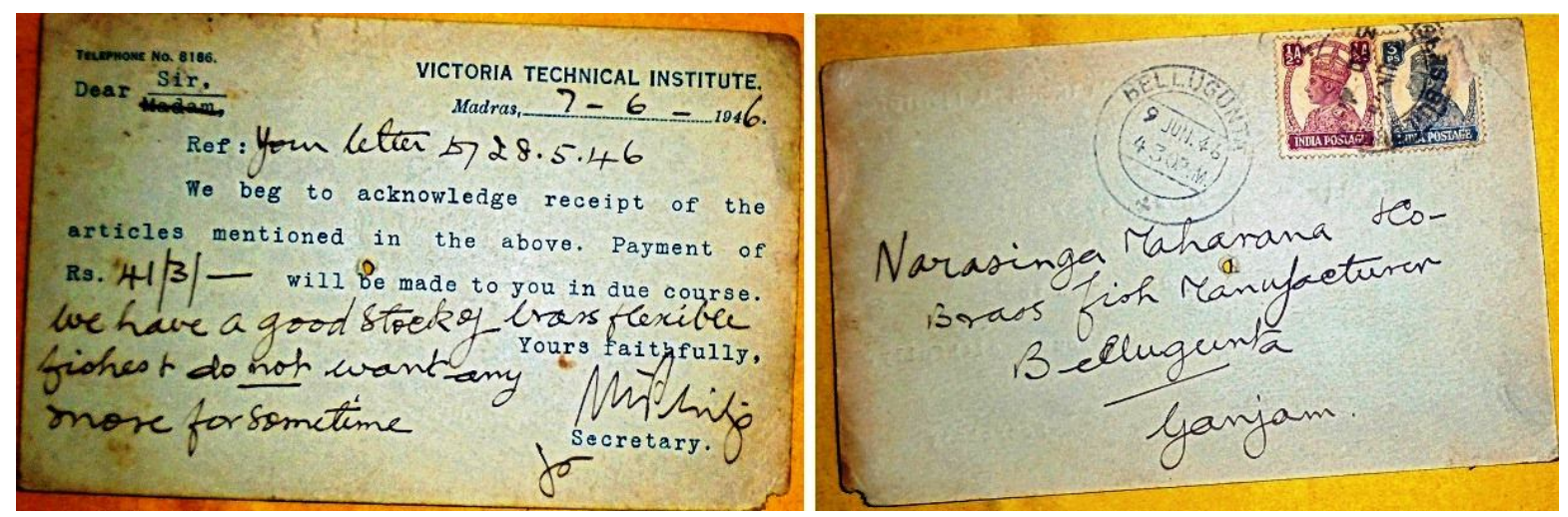

Figure-6: A letter dated 07.06.1946 addressed to Sri Narasinga Moharana, descendent of Sri Bhikari Moharana (Photography by Author)

\subsubsection{Knowledge Shift-II}

A branch of Sri Bhikari Moharana's craft-family is practicing the same craft in K-Noagad village. This village is situated in Bellaguntha Block area itself. Sri Harekrishna Moharana had a sister, who was married in K-Noagad with a gentleman, who was belonging with "Sahoo" family. Here, Sahoo is a family name here and belonging to the same social community, as of "Moharan"- both are brass smith ${ }^{28}$ or "Kansari" community members and social mirages are acceptable between both of these families, in Bellaguntha area. Sri Harekrishna Moharana had a sister, who was married in K-Noagad. As Sri Harekrishna Moharana was a loving uncle, he trained his sister's children, Sri Bharat Sahoo and his brother, along with his own children. Post completion of his craft-training in Bellaguntha, Sri Bharat Sahoo, went back to his paternal village K-Noagad, and start practicing the flexible brass craft with his family members.

\subsubsection{Knowledge Shift-III}

Now a day, a number of trained and induced, flexible brass craft artisans also exist in Bellaguntha area. Most of these artisans are being trained by the master craftsman, to develop a pool of professionally trained and skilled human resources, at local level. These newly trained artisans are belonging from different sociological communities and contributing in craft practices. These artisans are mostly working under supervision of a Moharana or a Sahoo, community master craftsman.

\footnotetext{
${ }^{28}$ (Wikimedia Foundation, Inc., 2016)
} 


\section{Unique Features of Flexible Brass Craft}

\subsection{Re-Definable Biomimetic Form}

The most appealing element in a flexible brass product is its biomimetic qualities. Biomimicry means, an approach for product, process and policy innovations which is inspired from the nature's time-tested patterns and strategies ${ }^{29}$. Among all of the flexible brass craft products, produced in Bellaguntha area today are mostly of the aquatic creatures, like- fishes and lobster; and semi-aquatic creatures, like- snakes and tortoise etc. In a flexible brass craft product, there are three different anatomical parts are commonly available, named as, head, abdomen and tail. The head and tail parts are of static in nature, by its construction, but are well textured and are also able to define the overall visual appearance of the real creature, as it is found in their own natural habitat. The 'real-life like' physical movements are achieved through the construction of its abdomen part- through skillful craftsmanship. Actually, this abdomen part, through its living body like, physical movements on its surfaces, providing such product a real life like "unique" appeal to the target end user.

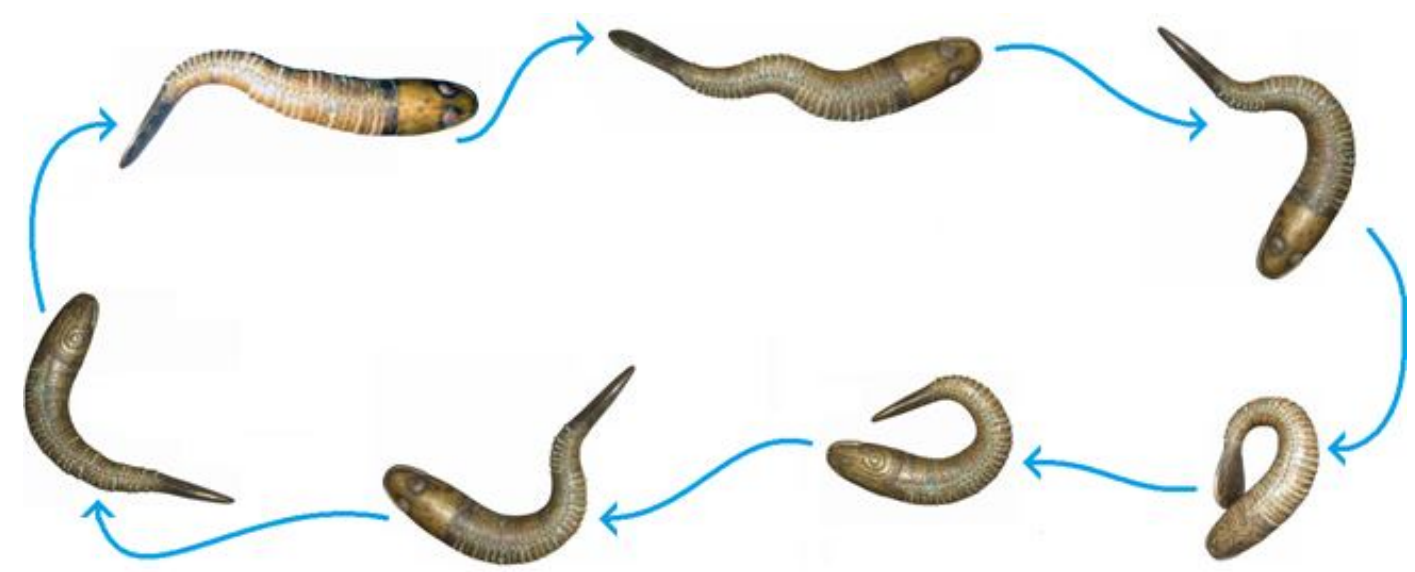

Figure-7: Demonstration of biomimetic physical movements by a flexible brass product (Author Illustrated)

The basic principle is based over human sensory organs. There are five sensory organs in human being $^{30}$. These sensory organs are nature given input devices of human being, creates both-way, non-formal communication with our surrounding living spaces. Any product, which is able to create such communication, through more than one human sensory organ, creates more strong impact, by breaking visual and physical monotony. Flexible brass products are able to create such creative and cognitive impacts ${ }^{31}$ over the end user's thinking process through its biomimetic redefinable physical structure. This product quality is achieved through its re-definable abdominal formations and supported by the head and tail parts, in each of these skillfully crafted products. Please refer figure-7 above.

\subsection{Textures}

\subsubsection{Flexible Brass Fish}

\footnotetext{
${ }^{29}$ (The Biomimicry Institute, 2008-2016)

30 (The Nemours Foundation/KidsHealth, 2015)

${ }^{31}$ (Nathalie Bonnardel, 2010)
} 
On the basis of textures, a common flexible brass fish form, can be segmented into four sub sections, i.e., head textures includes two circular eyes, one parallel curved lined mouth and two dorsal fins with ray marks; abdominal wavy parallel textures; dorsal curved fin textured; and tail textures with segmented curves (please refer figure-8).

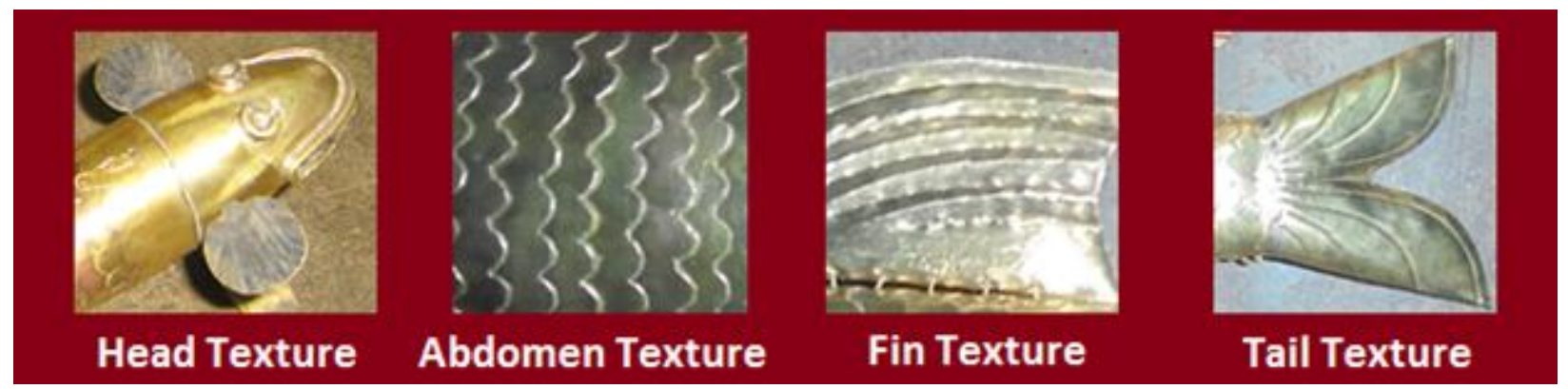

Figure-8: Textures of a flexible brass fish (Photography \& Illustration by Author)

\subsubsection{Flexible Brass Lobster}

On the basis of textures, a common flexible brass lobster form, can be segmented into three sub sections, i.e., head textures includes multiple textured parts, with two circular eyes and two wired tentacles; abdominal parallel and plain, but circular textures; and tail textures with two different directional set of parallel lines and curves (please refer figure-9).

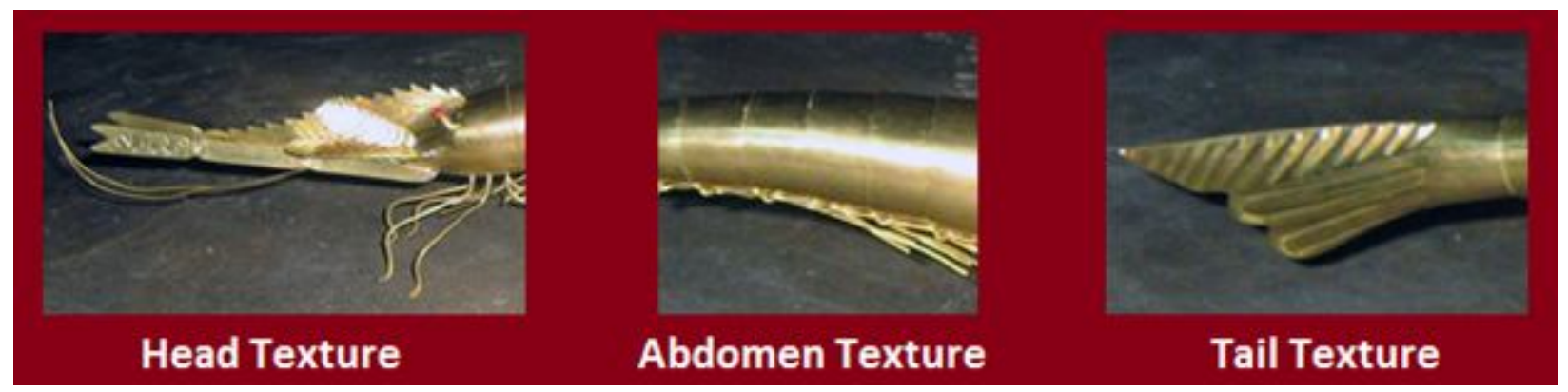

Figure-9: Textures of a flexible brass lobster (Photography \& Illustration by Author)

\subsubsection{Flexible Brass Snake}

On the basis of textures, a common flexible brass snake form, can be segmented into four sub sections, i.e., head textures includes curved line marks, lined edges, two weird teeth and two circular eyes; neck texture carries parallel and plain circles; abdominal textures carries multiple curved lines; and tail textures carries a set of small lines (please refer figure-10).

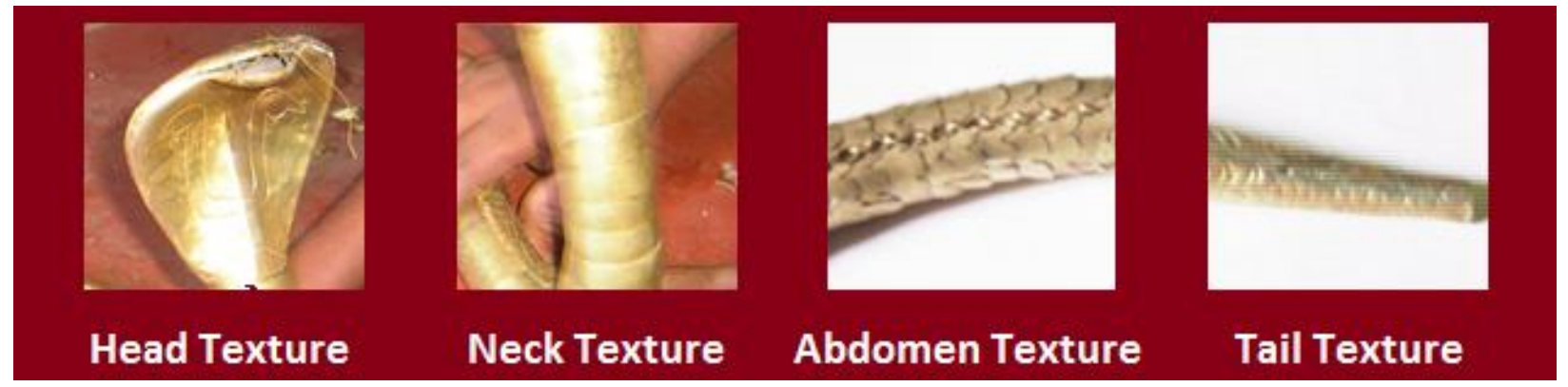

Figure-10: Textures of a flexible brass snake (Photography \& Illustration by Author)

\section{Common Form Composition}


On the basis of common and broad form study, a flexible brass product can be distinguished into three common parts, at macro level. Although, during a micro level study of each individual flexible brass form, more sub-sections, like, a snake form includes neck part, while a lobster head in itself carries a cluster of tentacles and other defining compositions, and fishes carries dorsal fines.

\subsection{Head Part}

Head is seen as a three dimensional parabolic structure. This part is non-flexible in nature and getting assembled with abdomen.

\subsection{Abdomen Part}

This part is a composition of wire assembled several independent brass rings. The numbers of rings are being counted on per inch basis. Their widths vary between o.8 inches to 1.6 inches and are depending over the final expected length and allowable movement range of the product under manufacturing. Abdomen is flexible part in most of the creatures crafted in Bellaguntha.

\subsection{Tail Part}

The tail part's form and construction differs from creature to creature, but, usually are of the nonflexible in their physical nature. Tail is a texture dominant part.

The head and tail parts are non-flexible, whether the abdomen part is flexible and rhythmic. Actually the abdomen part carries major attraction appeal. Earlier, artisans were making tail parts weighted- by filling in, lead inside. This was supporting abdominal movements more rhythmic. But now a day no any artisan is producing lead filled tail, because this enhances weight of a flexible brass product, as well as creates negative issues during international trades, as some nations are considering lead as a radioactive element.

The manufacturing process of a flexible brass product is a phase wise craft practice. After making all of the independent segments, final assembly is taking place by using unique wire knotting technique.

\section{Raw Materials}

\subsection{Bass as Basic Raw Material for Flexible Brass Craft}

\subsubsection{Brass as a Craft Friendly Material}

As this craft's name reflects in itself, brass is the basic raw material for its entire craftsmanship activities. Brass is a well explored and artifact friendly metal, which is an alloy of copper and zinc. Its gold like rich visual appeal and low melting qualities attracted the end user communities, since thousands of years. This soft, ductile and corrosion resistant alloy gets melted on approximately $90^{\circ} 0^{-}$Celsius $^{32}$. In Indian subcontinents, brass is used for different purposes since around $2000 \mathrm{BC}^{33}$. As, this is an alloy of two elements, so, both of the element's proportion changes are possible during manufacturing. Due to its multiple craft-friendly properties, brass is considered as an ideal raw material for art, craft and design practices today, among others, some of them are, long lasting life with less corrosion; requires little maintenance; color provides rich

\footnotetext{
${ }^{32}$ (Minhat, 2010, pp. 01-02)

33 (Wikimedia Foundation, 2016)
} 
visual appearance; varying degrees of hardness or softness makes brass malleable and easy to engrave; and difficult to tarnish easily etc.

\subsubsection{Historical Background: Selection of Brass as Basic raw Material}

According to artisans of Bellaguntha, their fore parents received technical expertise in different metals and their properties in the royal armory. Where, on the basis of their expertise, they understood above qualities of brass and after initial prototyping, they found brass as a craftfriendly material, which was able to fulfill their raw material requirements for flexible brass craft practices. Further, this common raw material selection tradition had been followed by his craftschool followers, as their occupational tradition.

10.2. Why Brass Only! Why Not Wood, Silver or Gold?

During recent times, few other material-based explorations were also taken place in Bellaguntha area, with some other materials, like, wood, silver, gold etc. as an option of brass, but these explorations were unable to replace brass as the basic raw material from the flexible craft's regular market, due to its competitive cost effeteness on final end-product costing, visual similarity of brass with gold like highly expensive material, socio-cultural acceptance in surrounding Hindu and other folk religion follower consumers and end-users etc.
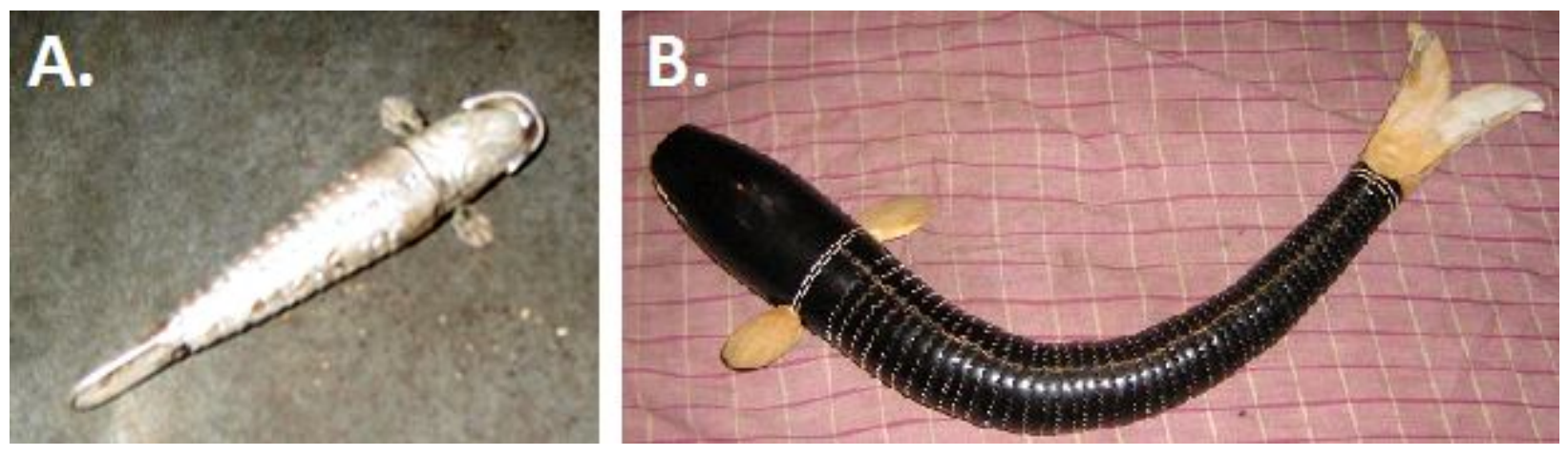

Figure-11: (A.) A non-regular flexible fish form in Silver and (B.) A non-regular flexible fish form in Wood (Photography by Author)

Although on specific demands by consumers, Silver, Gold and Wooden flexible forms are also being developed by flexible brass artisans in Bellaguntha area occasionally. But as the production rate of such diversified-material specific, flexible products are too low, so are unable to be counted as a regular flexible product, over which the flexible craft-economy can be relied. So, these diversified material based exceptional explorations can be called as non-regular material oriented explorations. The high material costs involved with Gold and Silver like precious metals and production-skill related technical diversification with Wood are some of the limiting factors, which let these materials limited to compete with the wider acceptance of brass, as the basic material among traditionally skilled craftsmen of Bellaguntha area and its established demand and supply chain among audiences since last several centuries.

\subsection{Types of Brass Used in Craft}

Fresh brass sheets and wires with high copper contents are the basic raw materials for flexible brass craftsmanship. No any use of brass scraps or recycled brass had been observed under re-use, by Flexible Brass Craft artisans. These scraps have been sold to other brass smiths in near areas, who purchase these scraps for brass molding purposes. 
Mostly raw materials are getting procured from local raw brass merchants, located in Bellaguntha area or nearby locations, like- Bhanjanagar and Ganjam. Usually it had been observed, that raw material costs in local markets are higher than the prices in Bhubaneswar and Kolkata's brass market places. According to local brass merchants, the transportation charges and other related overheads are responsible for the raw material price rises in local markets.

So, whenever an artisan receives higher manufacturing demands, they often prefer to procure the required raw material quantities from Bhubaneswar or Kolkata's brass markets. It helps them to control their end-product costing and also helps them to enhance their margin of profit. Figure-12 displays basic raw materials used for Flexible Brass Craft practices.
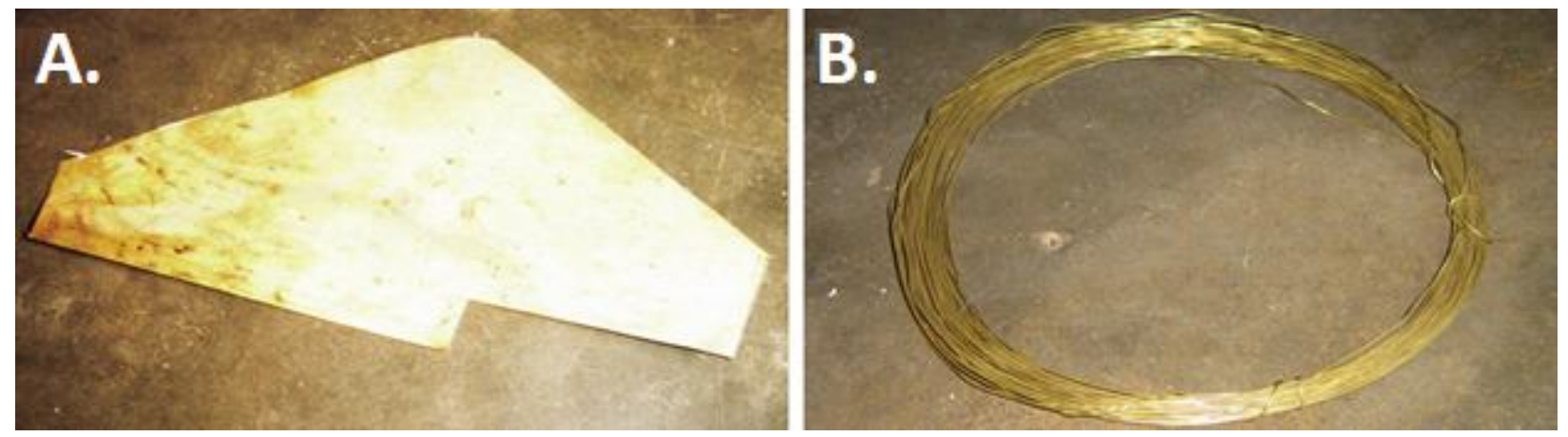

Figure-12: Basic raw materials of flexible brass craft: (A.) Fresh brass sheet and (B.) Fresh brass wire (Photography by Author)

Here this important to understand that each single unit of a flexible brass product requires different thicknesses of brass-sheets to develop its different set of components. The thickness of a brass sheet is being calculated into gauges ${ }^{34}$. Usually brass sheet thickness varies between, 20 gauges to 30 gauges. For example, to create a 10-12 inch longer form, a 20 gauge brass sheet is required to develop dorsal fin of a brass fish form; while a sheet thickness of 22 gauges is required to develop head and stand parts for fish and lobster forms; a 26 gauges thick brass sheet is required to develop tail segment in fish and snake forms; while a sheet thickness of 30 gauges is required to develop abdominal rings in fish and snake forms. These sheet thicknesses are variable and are depending over the dimensions of the end product, under manufacturing. The table-1 illustrates a summary of brass sheet thicknesses required for a 10-12 inch long flexible brass product.

\begin{tabular}{|c|c|l|}
\hline SN & Brass Sheet Thickness & \multicolumn{1}{|c|}{ Purpose of Use in Craftsmanship } \\
\hline o1. & 20 gauges & To develop the dorsal fines \\
\hline 02. & 22 gauges & To develop the head part \\
\hline 03. & 22 gauges & To develop the stand \\
\hline 04. & 26 gauges & To develop the tail part \\
\hline 05. & 30 gauges & To develop rings for abdomen part \\
\hline
\end{tabular}

Table-1: Commonly used brass sheet thicknesses

\footnotetext{
34 (CustomPartNet, 2009)
} 
Similarly, the thickness of raw brass wire also varies, according to their different purposes. For example, a 10-12 inch long flexible brass product required to develop welded outer mouth peripherals and textured eye ring peripherals with a common or near common thicknesses; while the running knotted ribs are required to develop in lesser thicknesses, as it can perform better and even results during the parallel knotting process.

10.4. Additional Raw Materials Used in Flexible Brass Craft

Apart from the basic raw material brass, which forms approximately $99 \%$ of a flexible brass product form, there are some additional raw materials which are being used to complete the craftsmanship. All of them are required to enhance the end quality of these products. Some of them are responsible to create and enhance the physical definitions of a flexible brass product, like, an 'eye ball glass' is used to define eyes of the subjected creature; stand ribbits are being used to join supporting stand and main body of the product. Thin stainless steel wire is used to achieve precise joint placements before welding and removed after welding process. Liquefied lead is used as temporary filler and is used during the production of head and tail parts and removed completely after outer form and texture generation processes, by re-heating the head and tail parts. The welding mixture is being used to achieve brass joints strengthening. Dried wooden charcoal is used for furnace and other heating related processes. Industrial sandpapers of different numbers are used to remove unnecessary welding marks and sharp edges etc. for polishing and metal surface enhancement purposes, locally available dried etha fal (in local Odiya language) seeds, which is also called as the Ritha in Hindi, and as the Soap Nut ${ }^{35}$ in English, are being used with fresh water at the room temperature, which is applied with the coconut coir. The etha fal is non-toxic in nature. For packaging purposes, old newspapers and polyethylene packets are being used. Please refer figure-13 below.
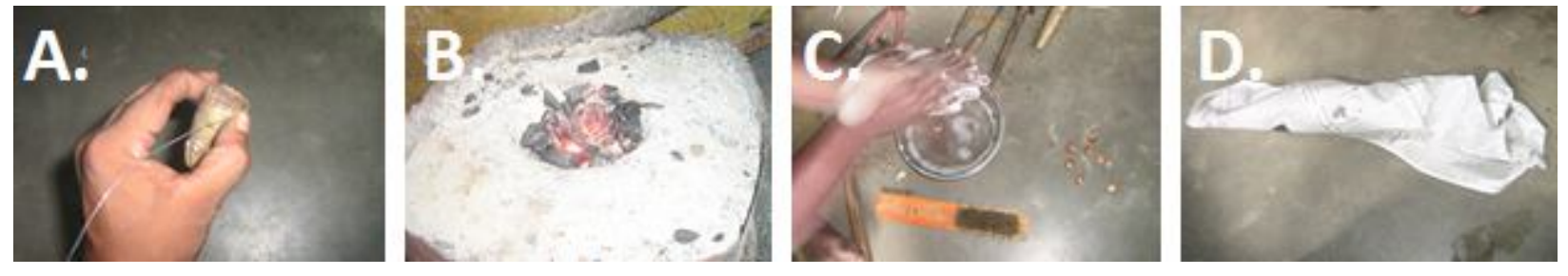

Figure-13: Few additional raw materials used in flexible brass craft: (A.) Steel wire for welding support, (B.) Dried wooden charcoal for firing, (C.) Etha Fal seeds for polishing and (D.) Old Newspaper for packaging (Photography by Author)

\section{Tools Used}

The flexible brass craft artisans of Bellaguntha are least dependent over the readymade tools market. They are highly expertise in developing their own tools, as per their craft related specific requirements. Except some of the universally accepted metal craftsman tools, like, hand drillers, pliers, hex-saw and other similar tools, they prefer to develop and repair tools in their own workshops as per needs. So, most of these utility specific, self-developed tools are named by artisans themselves like, Sabal, Guatiya, Mathna etc.; although few of the artisan-developed tools are named in near resembling English words as well, like, Edge Marker, Square Iron Base, Set of Curve Cutting Chisels etc. These given names are merely able to justify their broader uses specific classes, and every class carries a large collection of variations within themselves.

35 (Vinita, 2010) 


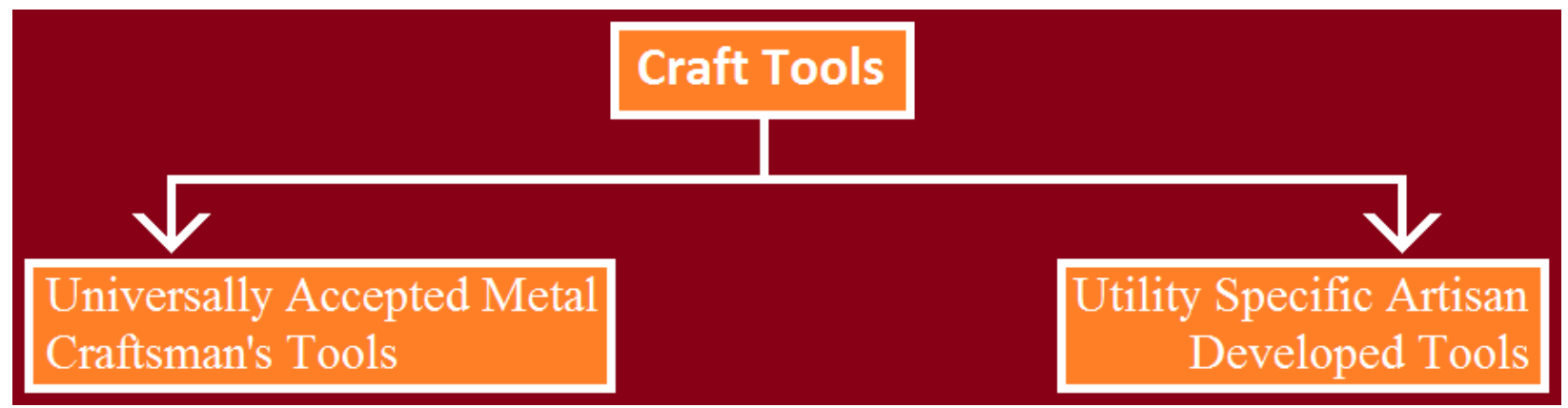

Figure-14: Broader types of tools being used by the flexible brass craft artisans in Bellaguntha (Classification by author)

A small collection of tools are illustrated in table-3. This table includes both types of tools being used by the flexible brass craft artisans of Bellaguntha, which can be classified as the "Universally Accepted Metal Craftsman's Tool" and the "Utility Specific Artisan Development Tools", please refer figure-14 above. These tools are available and can be procured from a regular metal tool shop. In table-3 below, the universally accepted metal craftsman's tools are indicated with “*” marks, while the artisan developed, utility specific tools are indicated with "\#” marks.

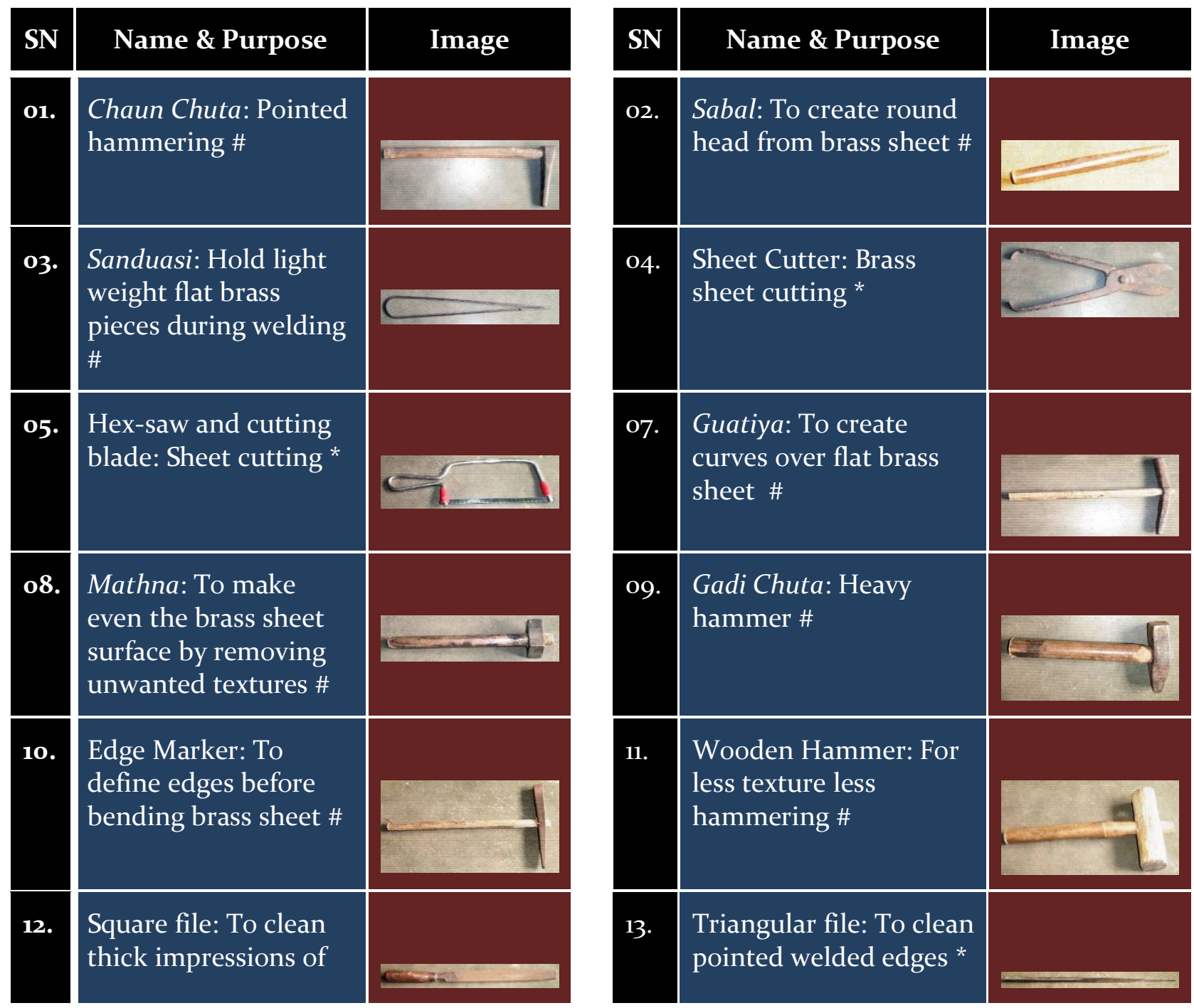




\begin{tabular}{|l|l|}
\hline welding layer * & $\begin{array}{l}\text { Pointed Plier: To bend } \\
\text { brass strip cuts * }\end{array}$ \\
\hline 16. & $\begin{array}{l}\text { Flat Head Plier: To } \\
\text { bend and press brass } \\
\text { wire pieces during } \\
\text { assembling of brass } \\
\text { segments * }\end{array}$ \\
\hline 18. & $\begin{array}{l}\text { Pipe Threading } \\
\text { pointer set (Inner): } \\
\text { Threading pipe * }\end{array}$ \\
\hline 30. & $\begin{array}{l}\text { Hand Driller: For } \\
\text { drilling thicker gauge } \\
\text { brass sheets * }\end{array}$ \\
\hline 20. & $\begin{array}{l}\text { Pointer: To create } \\
\text { small hand puncher } \\
\text { and for drilling of } \\
\text { brass sheet rings \# } \\
\text { pointer (Outer): } \\
\text { Threading pipe * }\end{array}$ \\
\hline 22. \\
\hline $\begin{array}{l}\text { Thexture Creators: Eye } \\
\text { and mouth texture } \\
\text { creating over brass } \\
\text { wire * } \\
\text { sureven brass sheet } \\
\text { surfaces flat \# }\end{array}$
\end{tabular}

\begin{tabular}{|c|c|c|}
\hline 15 & $\begin{array}{l}\text { Compass: Circular } \\
\text { marking on brass sheet } \\
\text { * }\end{array}$ & \\
\hline 17. & $\begin{array}{l}\text { Pipe Threader (Inner): } \\
\text { Inside threading * }\end{array}$ & $E$ \\
\hline 19. & $\begin{array}{l}\text { Pipe Threader (Outer): } \\
\text { Outside threading * }\end{array}$ & \\
\hline 21. & $\begin{array}{l}\text { Cleaning and Polishing } \\
\text { Brush: Cleaning the } \\
\text { brass surface and } \\
\text { polishing the finished } \\
\text { product * }\end{array}$ & \\
\hline 23 & $\begin{array}{l}\text { Sabal Aadhar: To make } \\
\text { small brass pieced } \\
\text { closer to eye level. It is } \\
\text { used with a wooden } \\
\text { base support \# }\end{array}$ & \\
\hline 25 & $\begin{array}{l}\text { Flat Chisel: To cut brass } \\
\text { sheet and wire into } \\
\text { small pieces \# }\end{array}$ & \\
\hline 27. & $\begin{array}{l}\text { Square Iron base: To } \\
\text { make uneven brass } \\
\text { sheet surfaces even \# }\end{array}$ & \\
\hline 29. & $\begin{array}{l}\text { Lakari Sabal: Used as } \\
\text { the base for drilling } \\
\text { brass sheet rings \# }\end{array}$ & \\
\hline 31. & $\begin{array}{l}\text { Plier: Multi-purpose } \\
\text { uses- wire cutting, } \\
\text { small sheet treatments }\end{array}$ & $=$ \\
\hline
\end{tabular}




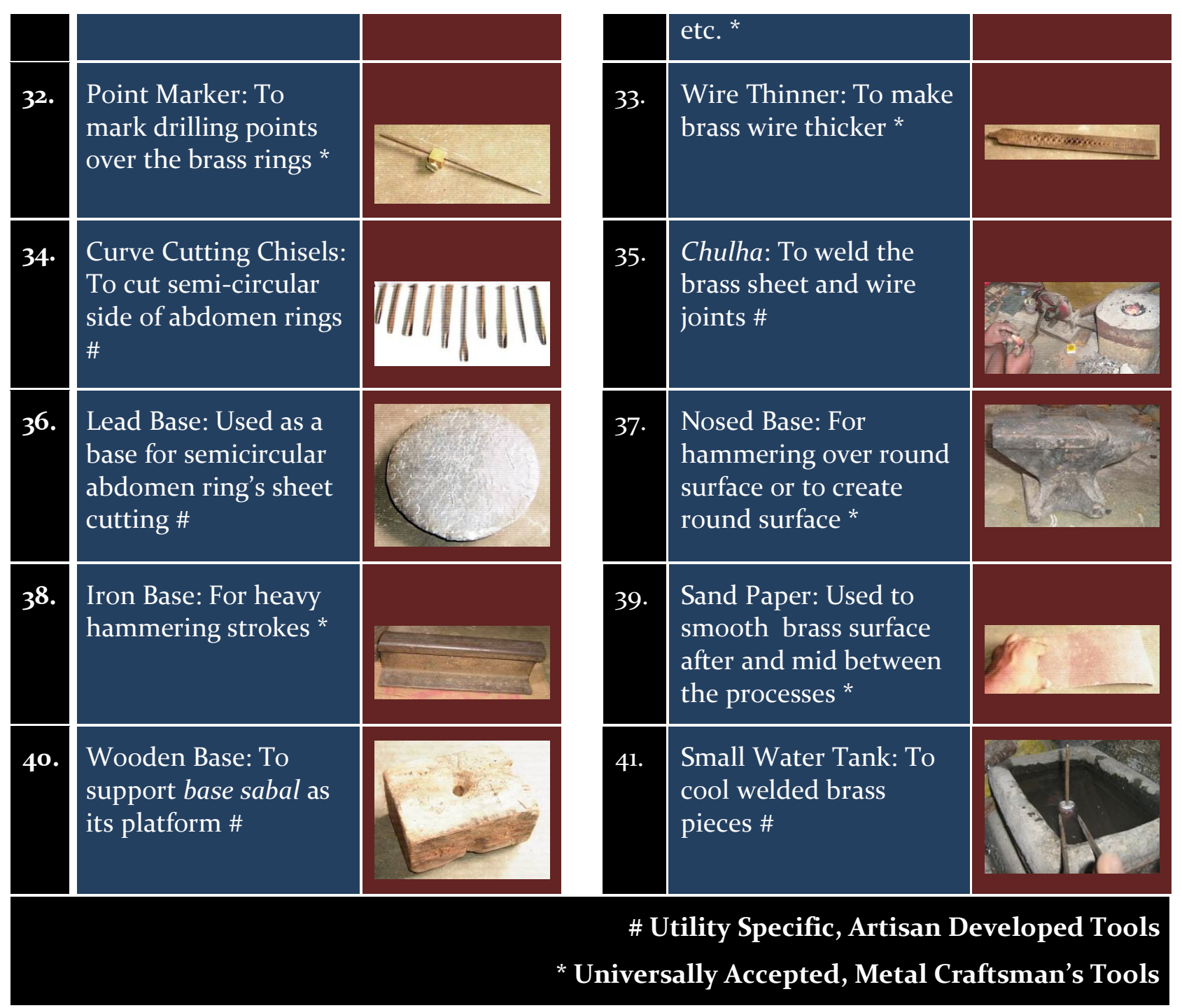

Table-2: Some of the tools being used by the flexible brass craft artisans in Bellaguntha (Photography by Author)

\section{Craftsmanship Processes}

In flexible brass craft, production is a phase wise process, where every phase is subdivided into several sections. As discussed above, there are many flexible brass forms, like, flexible brass snakes, flexible brass lobsters, flexible brass tortoise and flexible brass fishes are being crafted on regular basis in Bellaguntha. As the physical-forms of these brass creatures are different from each other, so, the component craftsmanship processes are also differing from each other. Although, involved primary processes, most of the tools and artisan's skill sets are common in nature.

For this study, the craftsmanship process of a flexible brass fish was taken for case study purposes, as brass fishes are most demanding product, among other flexible brass forms, these days. A flexible brass fish can be subdivided into 04 broader components, i.e., head component, dorsal fin component, abdomen component and tail component.

In terms of comparative dimension share, in a complete flexible brass fish length, the tail component contributes $25 \%$, which is equal to the head component's share. So, the length 
contributions in an entire fish form is contributed by $25 \%$ through head component and $25 \%$ through tail component; which is altogether $50 \%$ of the entire end product's length in horizontal axis. The remaining $50 \%$ length is contributed by the abdomen component. In summary, this composition can be understood through table-3.

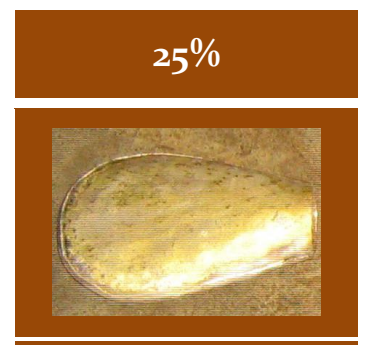

Tail Component +
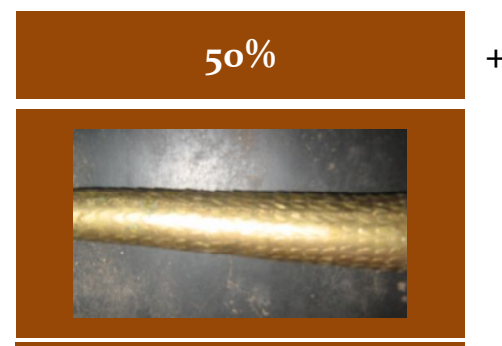

Abdomen Component +
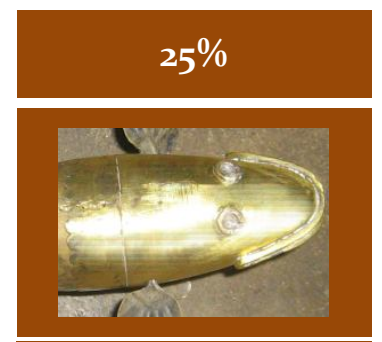

Head Component $=$
$=$
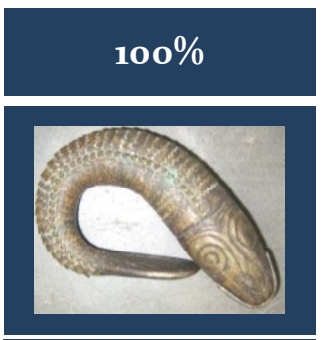

Total Length

Table-3: Contribution in percentage by components in a complete flexible brass fish form (Photography \& Illustration by Author)

12.1. Head Component

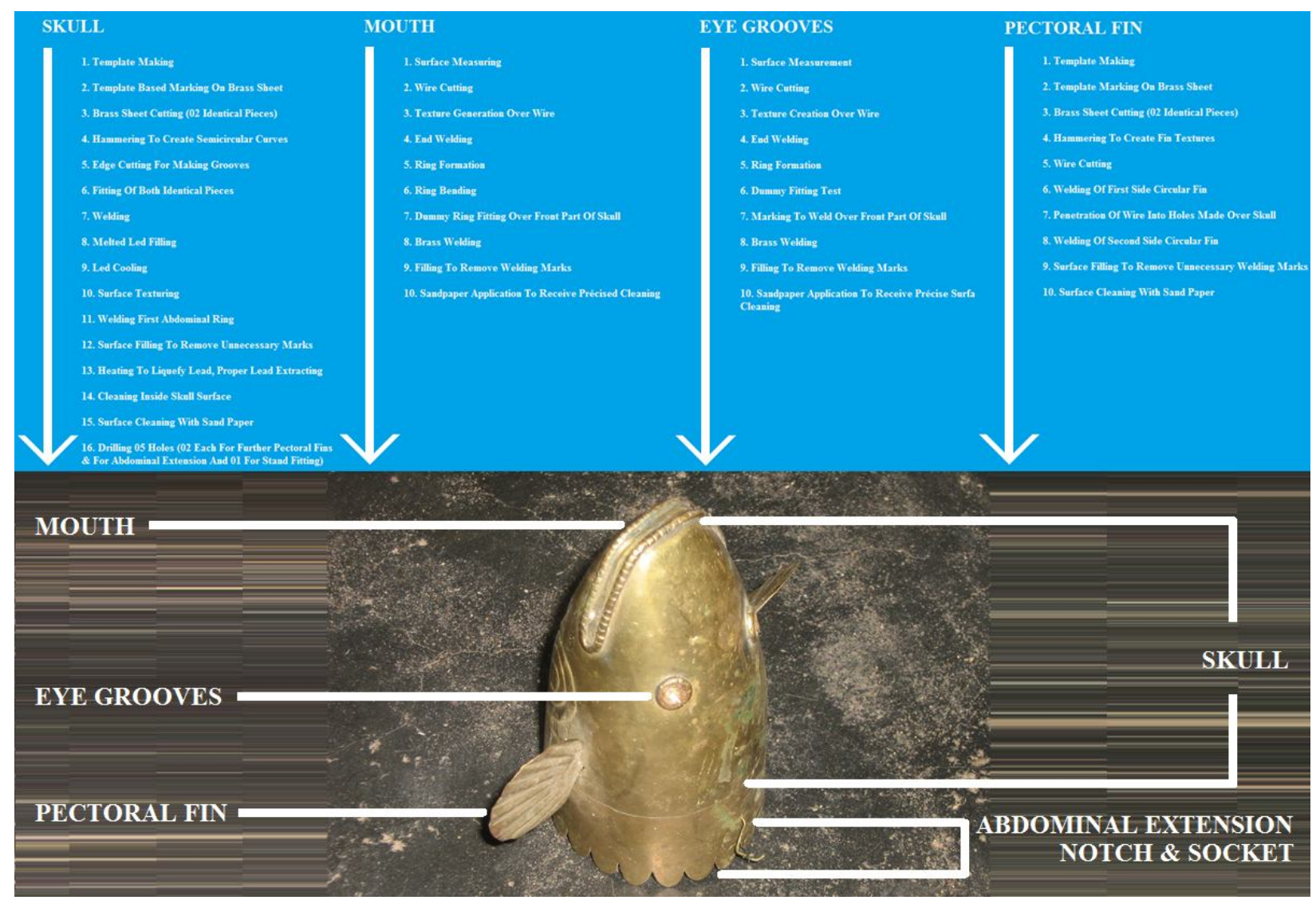

Figure-15: The craftsmanship stages involved in a head component formation, along with end result (Photography \& Illustration by Author)

This part is made up of two sheets of same gauge. Development of this section is considered as one of the most critical and time consuming exercise for crafting a flexible brass fish form. The length proportion calculation for a fish head is- $25 \%$ of the total length of a finished fish form. During this study, it had been observed, that the head part (length $2^{1 / 2}$ inches) of a 10 inch long 
fish form requires around 04 continue working hours to complete it. On the basis of flexible brass craftsmanship, the head part development is considered as the most complex exercise. The process of head component development is illustrated in figure-15 below.

The development of a head component involves 04 major production stages within itself, i.e., the development process of skull, mouth, eye grooves and pectoral fin. These stage wise developmental processes are illustrated as follows.

12.1.1. Development Process of Skull

The process of a flexible brass fish form's skull part development is illustrated as follows:

Template drawing over a hard paper > Template based marking on brass sheet> Brass sheet cutting (o2 identical pieces) $>$ Hammering to create semicircular curves $>$ Edge cutting for making grooves $>$ Fitting of both identical pieces $>$ Welding $>$ Melted led filling $>$ Led cooling $>$ Surface texturing $>$ Welding first abdominal ring $>$ Surface filling to remove unnecessary surface marks $>$ Heating to liquefy lead, proper lead extracting $>$ Cleaning inside skull surface $>$ Surface cleaning with sand paper $>$ Drilling 05 holes (02 each for further pectoral fins \& for abdominal extension and or for stand fitting). [Process concluded]

12.1.2. Development Process of Mouth

The process of a flexible brass fish form's mouth part development is illustrated as follows:

Surface measurement $>$ Wire cutting $>$ Texture generation over wire $>$ Wire end welding $>$ Ring formation $>$ Ring bending $>$ Dummy ring fitting over front part of skull $>$ Brass welding $>$ Filling to remove welding marks > Sandpaper application to receive précised cleaning. [Process concluded]

12.1.3. Development Process of Eye Grooves

The process of a flexible brass fish form's eye groove part development is illustrated as follows:

Measurement of surface $>$ Wire cutting $>$ Texture creation over wire $>$ Wire end welding $>$ Ring formation $>$ Dummy fitting test $>$ Marking to weld over front part of skull $>$ Brass welding $>$ Filling to remove welding marks $>$ Sandpaper application to receive précised cleaning effect. [Process concluded]

\subsubsection{Development Process of Pectoral Fin}

The process of a flexible brass fish form's pectoral fin part development is illustrated as follows:

Template drawing over a hard paper $>$ Template marking on brass sheet $>$ Brass sheet cutting (o2 identical pieces) $>$ Hammering to create fin textures $>$ Wire cutting $>$ Welding of first side circular fin $>$ Penetration of wire into holes made over skull $>$ Welding of second side circular fin $>$ Surface filling to remove unnecessary welding marks $>$ Surface cleaning with sand paper. [Process concluded]

\subsection{Dorsal Fin Component}

There are different types of dorsal fins are being developed by artisans. These differences can be observed in terms of their two dimensional outer forms as well as in the textures being generated over their surfaces. The selection of incorporable forms and textures are depending over the fish form under focus during the craftsmanship process. For example the dorsal fin of a Rehu Maccho (Labeo Rohita) is less wide then a Kou Maccho (Cyprinus Carpio) form. To achieve life-like physical appeal in the end product, movement-forms and textures of different real-fishes in their 
natural aquatic ecosystem ${ }^{36}$ are being studied carefully by these artisans and then imposed over the brass sheet accordingly.

Although this part is optional and not visible in all of the fish form variations being practiced in Bellaguntha. Usually these fin components are considered as external accessories or elements for external form composition, and, so, may be considered as an element for value addition in an end product.

The fin-component development process is displayed in figure-16, along with few pre-production, conceptual drawings, based over the studies of biomimetic movement patterns, outer forms and textures from observing different real-fishes in their natural aquatic ecosystems. Image also displays 04 different fins developed as an outcome of this process, in brass sheet.

\subsubsection{Development Process of Dorsal Fins}

The process of a flexible brass fish form's dorsal fin development is illustrated as follows:

Study of fish movement in natural aquatic ecosystem $>$ Form study of fin during movements $>$ Doodling of fin forms $>$ Selection of form $>$ Fin dimension identification $>$ Template drawing over paper $>$ Paper template cutting $>$ Marking on brass sheet as per template $>$ Brass sheet cutting $>$ Drawing fin ribs with a marker over the brass sheet cut $>$ Rail depression development over brass sheet $>$ Filling of surface $>$ Development of fine textures $>$ Application of sandpaper for cleaning $>$ Extra sheet edge trimming $>$ Welding of wire at ends (2-3 spots) OR drilling to create multiple holes at the adjoining fin end $>$ Finishing through filers $>$ Surface cleaning with sand paper. [Process concluded]

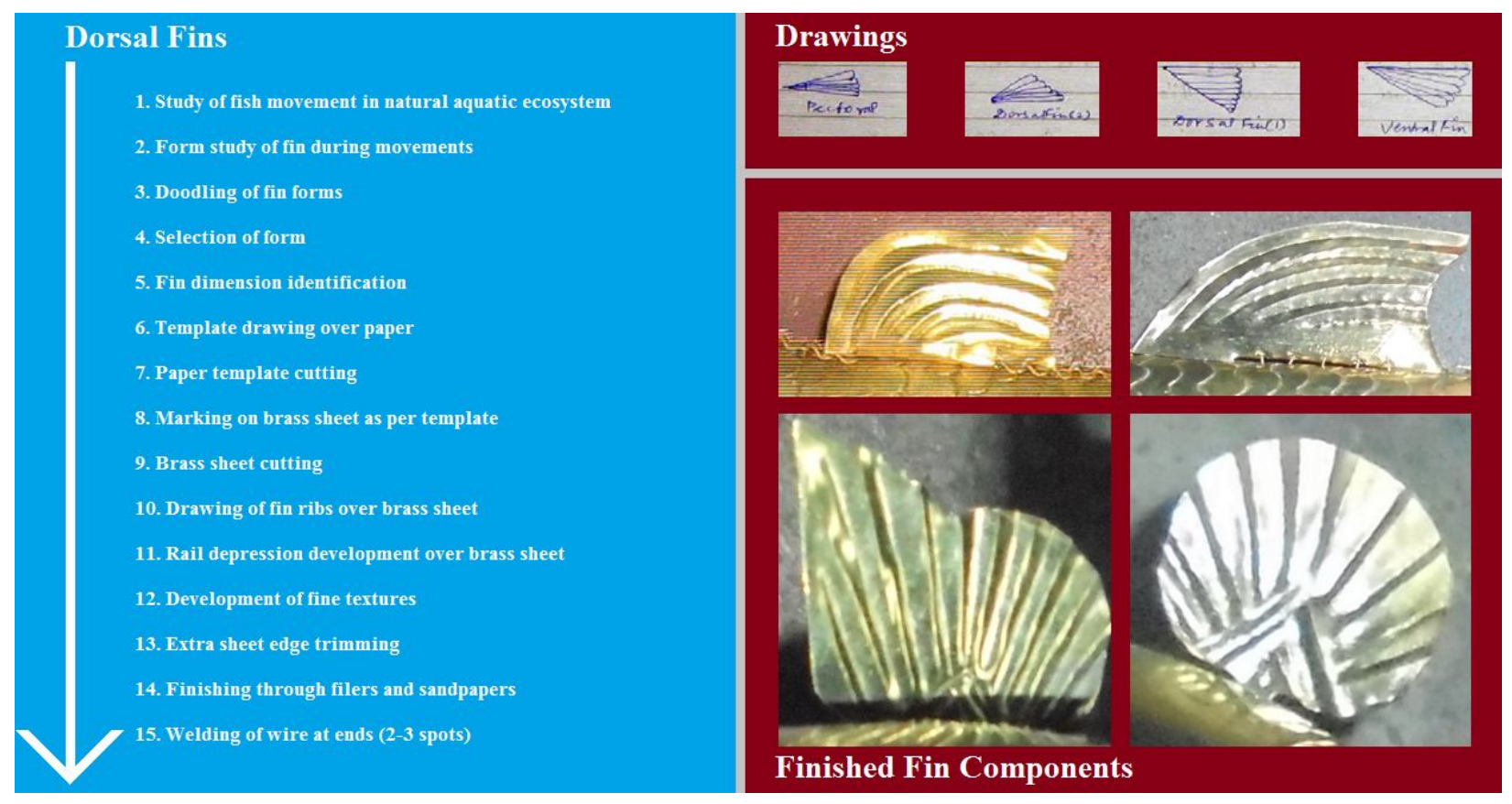

Figure-16: Craftsmanship stages involved in fin formation, along with few drawings and few end results (Photography \& Illustration by Author)

12.3. Tail Component

${ }^{36}$ (Lorenzen, 1996, pp. 627-642) 
Tail is the posterior component in a final flexible brass fish form. On the basis of craftsmanship, this part is considered as second on the basis of developmental complexities, and comes after fish head component- in terms of craftsmanship complexities. In terms of comparative dimension share, in a complete flexible brass fish length, the tail component contributes $25 \%$, which is equal to the head component's share. The tail-component development process is displayed in figure-17.

12.3.1. Development Process of Tail

The process of a flexible brass fish form's tail part development is illustrated as follows:

Template drawing over a hard paper $>$ Template based marking on brass sheet $>$ Brass sheet cutting $>$ Preparation of next identical piece $>$ Hammering to create semicircular curves $>$ Edge cutting for making grooves $>$ Fitting of both identical brass sheet pieces $>$ Edge welding $>$ Melted led filling $>$ Led cooling $>$ Drawing for rail making $>$ Texture generation $>$ Welding of last abdominal ring $>$ Surface filling to remove unnecessary surface marks $>$ Heating to liquefy lead, proper lead extracting > Cleaning inside surfaces with sand paper > Drilling 02 holes for abdominal extension. [Process concluded]
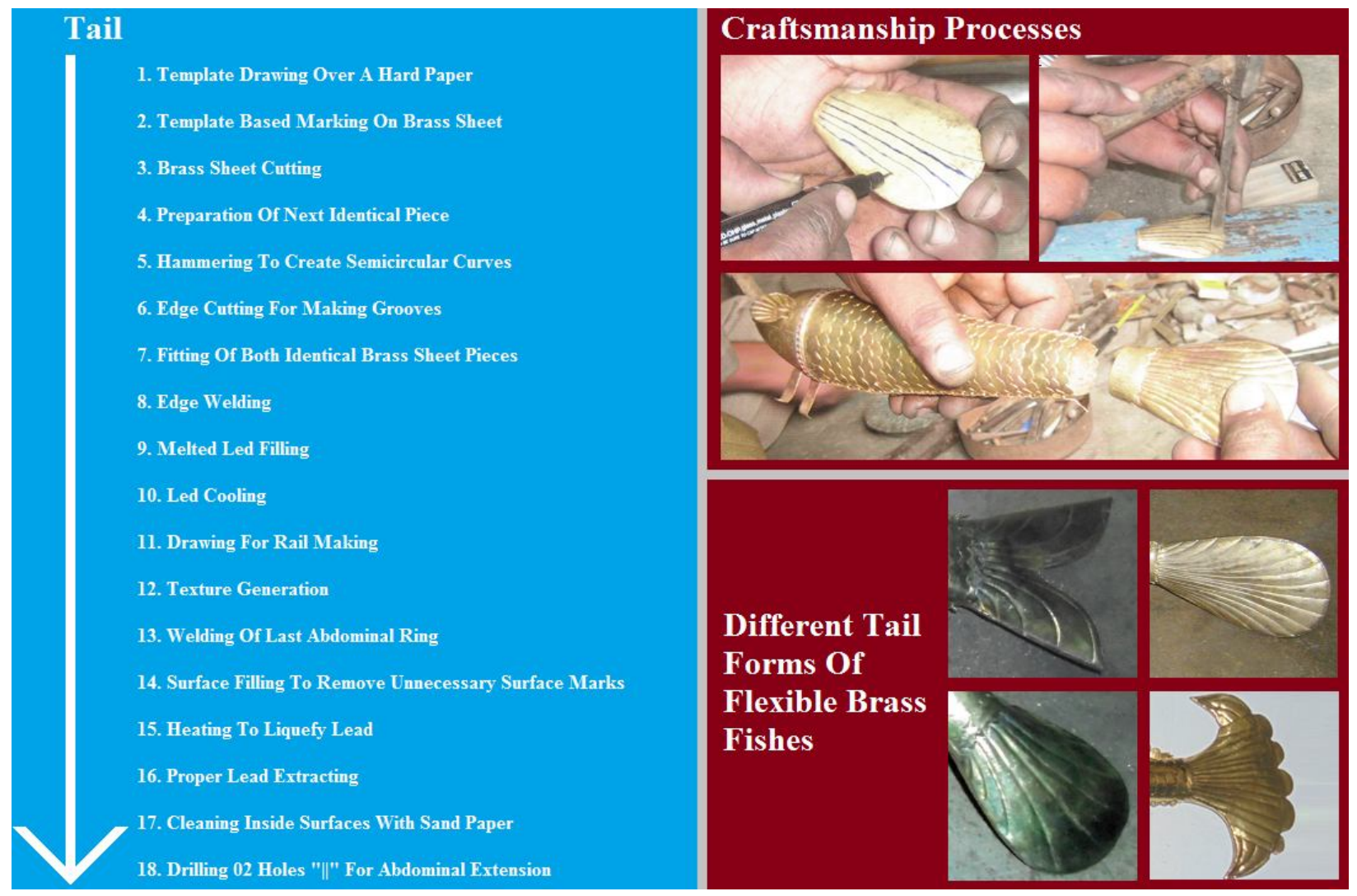

Figure-17: Phase-wise craftsmanship process with images and few brass fish tails (Photography \& Illustration by Author)

12.4. Abdomen Development and Component Assembling

This is the third stage of craftsmanship and usually artisans prefer to work over this stage after completion of head and tail components, as both of these components are used for defining first and last terminal segments for abdomen development phase. Stack-ability is the most important element for this phase to consider, when artisans need to fit each of the rings inside other. This requires very high rate of precision. The ring diameter varies from head to tail gradually. Every 
brass ring needs to be developed by brass sheets, where each individual ring needs to stack perfectly inside its presiding ring, in a particular orientation, so that the end product get sufficient breathing space for axial movement. After wire knotting, this phenomenon allows a flexible brass product to move and receive an overall life-like, physical and visual flexible appeal. Actually the abdomen is a composition of numerous brass rings. The count of rings per inch varies, according to the overall length of a subjected brass fish form. The abdomen-component development process is displayed in figure-18.

Here, this is important to understand, that in every subjected creature forms, being developed in Bellaguntha, the flexible abdominal rings are used as a common component with form-specific variations and provide these brass products a strong life-like, biomimetic appeal.

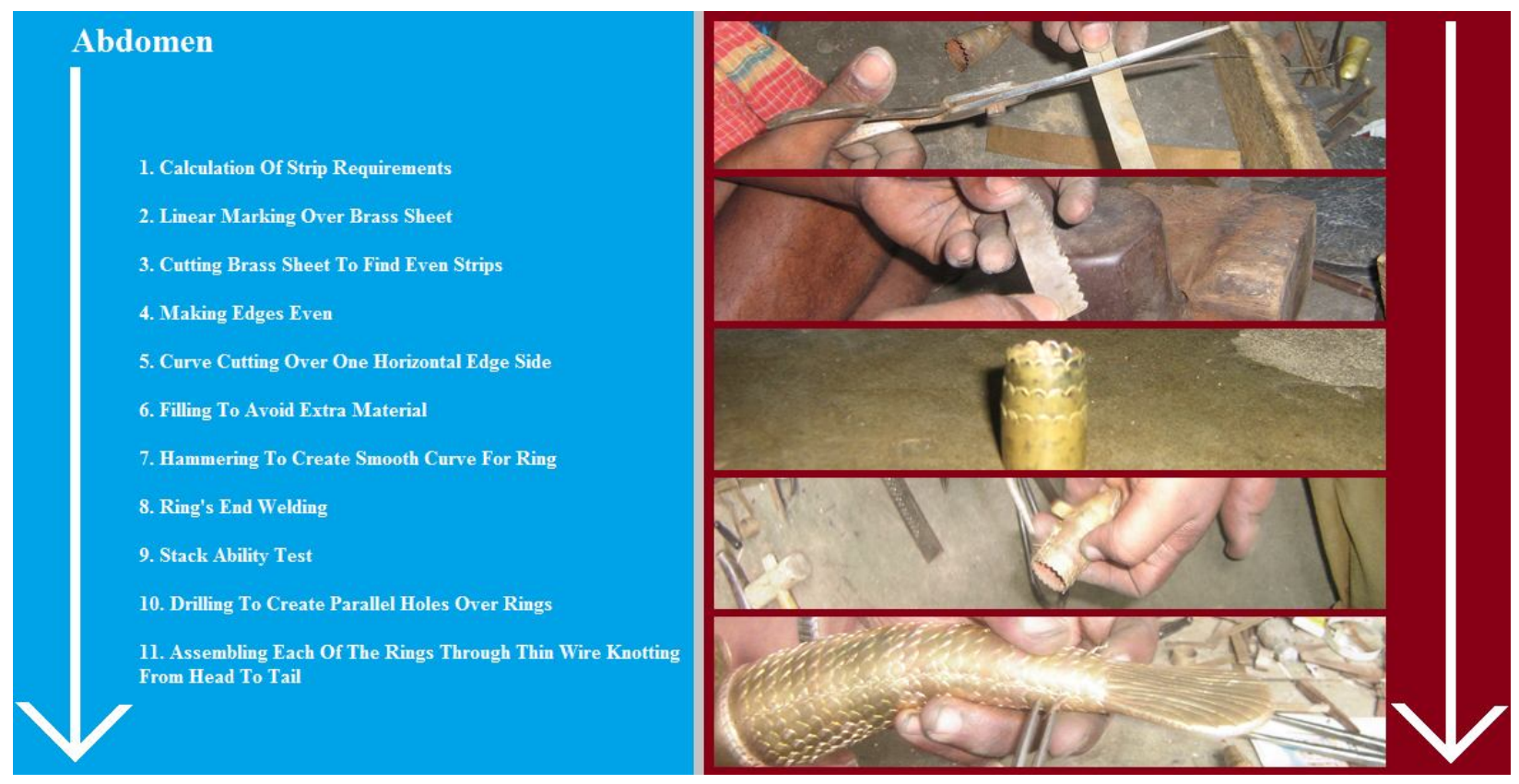

Figure-18: Phase-wise abdomen development under craftsmanship process (Photography \& Illustration by Author)

\subsubsection{Development Process of Abdomen}

Calculation of strip requirements $>$ Linear marking over brass sheet $>$ Cutting brass sheet to find even strips $>$ Making edges even $>$ Curve cutting over one horizontal edge side $>$ Filling to avoid extra material $>$ Hammering to create smooth curve for ring $>$ Welding $>$ Stack ability test $>$ Drilling to create parallel holes over rings $>$ Assembling each of the rings through thin brass wire knotting, which continues till head to tail. [Process concluded]

\subsection{Finishing and Polishing}

During this phase it is being required to remove extra and unused brass particles- if any, from the outer surface of a flexible brass product. Surface cleaning takes place by using different filers, i.e., flat, triangular and round; sandpapers of different numbers. The polishing process is displayed in figure-19.

For polishing the brass products, there are two types of processes are being followed, through chemical treatment and through Itha fal. The chemical treatment is required to remove strong and fine stain marks, created during welding and other involved craft-processes. The diluted Sulfur Nitrate is being used for such purposes. 


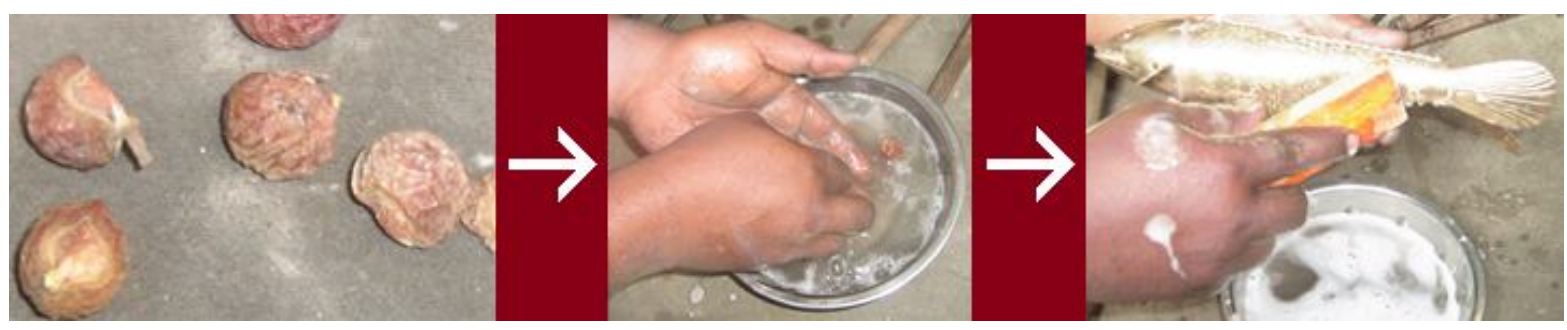

Figure-19: Different phases of Itha Fal application over a flexible brass product (Photography by Author)

The Itha Fal is next ingredient, which is being used for a flexible brass product's surface polishing purpose. This locally available dried seeds are available in the local surrounding forest areas, so traditionally used by artisans in Bellaguntha area. This seed is required to dip in fresh water at the room temperature and applied over the brass product's surface through a brush. This application gives glossy finish to flexible brass products. Itha Fal is purely a natural product and is able to provide signing over brass surfaces, which lasts for a duration of o6 months to o1 year.

\section{Final Products}

During field visits of Bellaguntha, this researcher came across with some final products, being manufactured these days on regular basis. Images of some of them are displayed in figure-18. The flexible brass tortoise form was not seen by this researcher during his field visits, as it was not under production in any of the visited workshop, at that point of time. Although, artisans informed that they are also crafting flexible brass tortoise forms on specified demands by the customers time to time, in limited number of units. During this visit, flexible brass fishes, flexible brass lobsters were observed under regular production in different workshops. The snake form was under production in one workshop only. Please refer figure-2o.

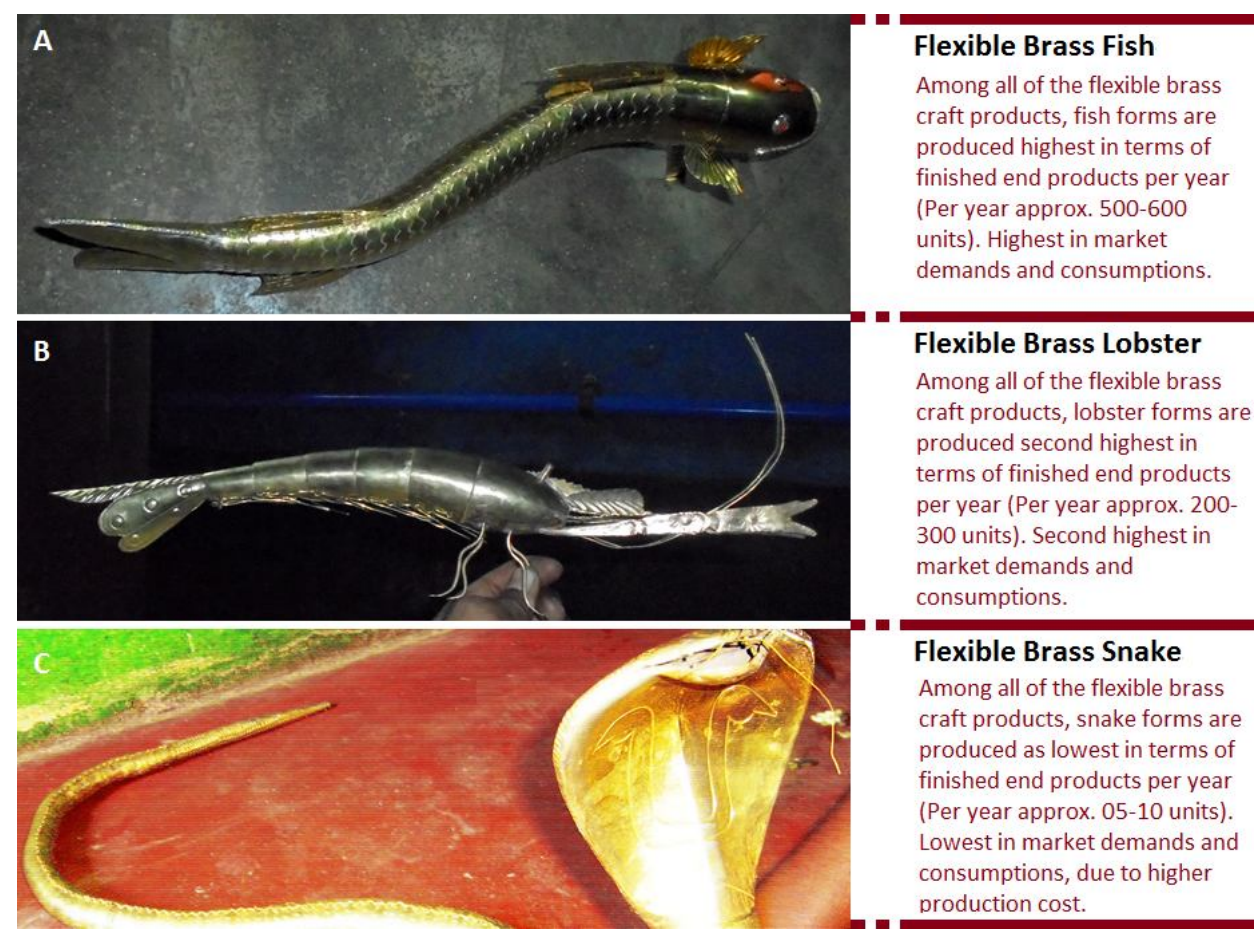

Figure-2o: Some of the well-known products of Flexible Brass Craft of Bellaguntha (Photography \& Illustration by Author) 
According to artisans, the flexible brass fishes are highest in demands by customers on regular basis, due to its socio-cultural importance in Hinduism. According to them, different folklore and mythological believes are working behind this product's highest demands. So, this form was seen under production, almost in every workshop.

The flexible brass lobsters are basically considered as a decorative product and its biomimetic form is the central appealing constraint, which attracts a common end user. In terms of demands, flexible brass lobsters are considered as the second highest selling product. So, this form was also seen under production, almost in every workshop.

The flexible brass snake forms can be categorized as a religious product, as mostly these forms are being developed on the demands made by Lord Shiva temples and by the pool of Lord Shiva devotees for offering purposes. The production cost for Snake forms are usually higher than other flexible brass forms, being manufactured in Bellaguntha, due to higher material, time and precision requirements for production purposes.

\section{The Master Craftsperson}

Sri Pradeep Kumar Moharana (Born in 1968) is the direct decedents of Sri Bhikari Moharana- the pioneer of Flexible Brass Craft of Bellaguntha (please refer section-7 above). He is the eldest son of Sri Ananta Moharana, and is considered as the Master Flag Bearer of this craft at Bellaguntha. Due to his excellent contributions, he has earned incredible respect among the flexible brass artisan's community.

He had learned craft practices under guidance of his father and veteran master crafts person Sri Ananta Moharana, and now training his next generation to carry forward the knowledge sharing tradition of his family. He is not only a veteran craftsperson, but also a well acclaimed craft trainer, who trained more than 50 other youngsters of Bellaguntha area to develop a pool of skilled and semi-skilled artisans.

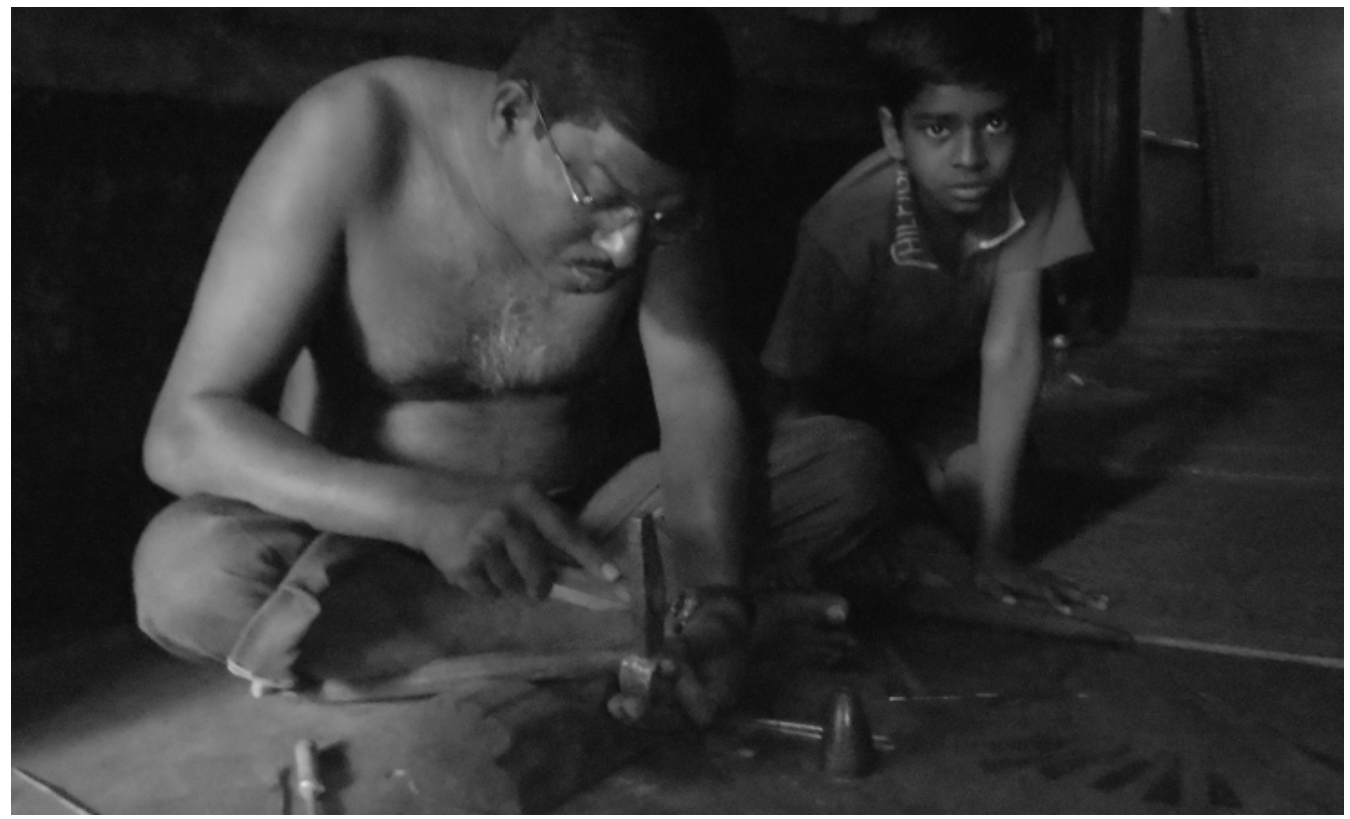

Figure-21: Master Craftsperson Sri Pradeep Kumar Moharana in workshop, with his son, who is under training under the active guidance of his father (Photography by Author) 
Sri Pradeep is also registered as a flexible brass craft artisan, in the office of Development Commissioner (Handicrafts), under the Ministry of Textiles of Government of India and now having approximately 40 years of work experience in this craft.

Due to his craftsmanship excellence he had received several local, state and national level recognitions from different governmental and non- governmental agencies. He is also running a workshop and training center, with the name of Narashinga Handicraft. Few of the recognition documents are displayed in figure-22 below, along with an image of his workshop's sign board.
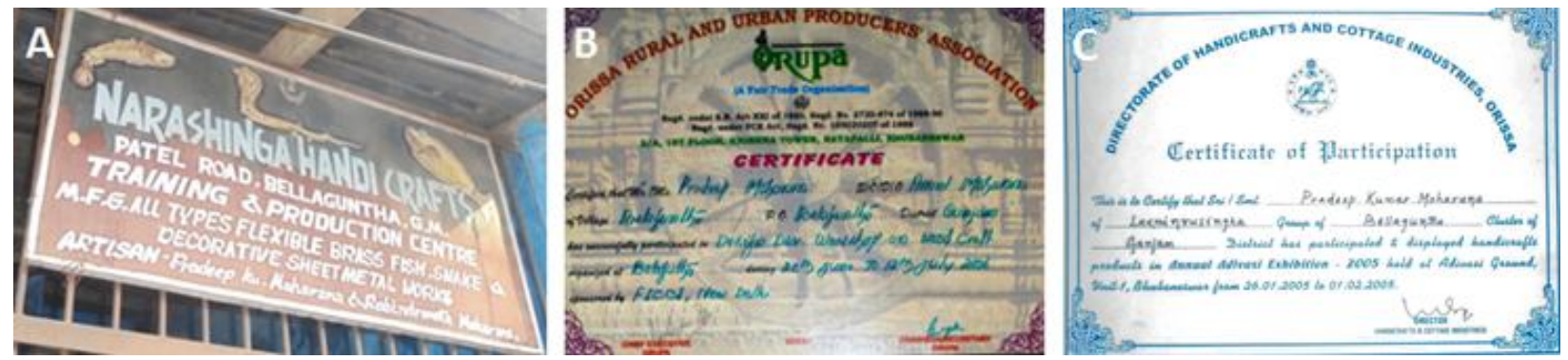

Figure-22: (A) Workshop of Sri Pradeep Kumar Moharana, “Narashinga Handicrafts”, and (B,C) Copies of two different recognition certificates of Sri Pradeep Kumar Moharana (Photography by Author)

14.1 How to Contact Master Craftsperson

One may visit or write to this master craftsperson at: M/S Narashinga Handicraft, Patel Road, Bellaguntha, Pin Code- 761119, Ganjam District, Odisha State, India.

\section{Conclusion}

Studying the dynamics of flexible brass craft of Bellaguntha was an interesting journey all together. Unavailability or partial availability of a systematic documentation about this $\mathrm{craft}^{37}$ attracted this researcher to visit the craft base, interact with artisans, study the potentials of existing products and understand the firsthand traditional knowledge database.

So that a document with systematic approach can be developed, which may able to provide basic information about its glorified history, traditional and indigenous techniques associated with this craft and finding existing potentials, so that another researchers and craft enthusiasts may understand its unexplored dynamics and may contribute further, with holistic approach, which may enrich the traditional and existing legacy of this craft.

\section{Acknowledgement}

This paper is dedicated to the entire community of Flexible Brass Craft artisans of Bellaguntha. Without their active supports during primary data collection, this paper cannot take its present form. A segment of this paper (discussed under 7.1.1.), was presented by this author, in $02^{\text {nd }}$ International Symposium on Entrepreneurship and Gender Development- Global Knowledge Exchange Network, with the title of "Entrepreneurial History of Flexible Brass Craft of Bellaguntha: Contributions of Mrs. Guni Maharana", organized by the National Institute for Entrepreneurship \& Small Business Development in Noida ${ }^{38}$, Ministry of Skill Development \& Entrepreneurship, Government of India, on $03^{\text {rd }}$ September, 2016, attended by the International delegates of around 30 countries, worldwide.

37 (Jha, 2016)

${ }^{38}$ (National Institute for Entrepreneurship and Small Business Development, 2016) 


\section{References}

1. Awesome Inc. (2014, August 06). Indian Princely State Mayurbhanj Fiscal Court fee and Revenue Stamps. Retrieved October 21, 2016, from Heritage of Indian stamps site:

http://indiastamp.blogspot.in/2014/o8/indian-princely-state-mayurbhanj-fiscal.html

2. Behera, B. (2016). ME AND MUSEUM/A field work on Art and Craft of Ganjam District of Odisha/Flexible brass fish of Belaguntha. Retrieved July 06, 2016, from http://shakmachanongmaithem.blogspot.in/2014/o8/banita-behera-igrms-bhopal-field-work.html

3. Benyus, J. M. (2002). Biomimicry: Innovation Inspired by Nature. New York City, U.S.A.: William Morrow Paperbacks.

4. Bhattacharya, S. (2011). Dhokra Art and Artists of Bikna: Problems and Prospects. Chitrolekha International Magazine on Art and Design, Vol. 1, No. 2, 10-13.

5. Blogarama.com. (2015, November 29). Fish Tales Etched in Brass. Retrieved July o8, 2016, from http://www.blogarama.com/Travel-Blogs/319939-Trips-Roads-Less-Travelled-Blog/878493-FishTales-Etched-Brass

6. Board of Secondary Education, Odish. (2014). About Us: Function of the Board. Retrieved August o8, 2016, from http://bseodisha.nic.in

7. Byrne, L. (January 2015). Eluded (Banded 2)/Chapter-7. Unknown: Logan Byrne.

8. Centers for Disease Control and Prevention. (2009). Arthritis Meeting the Challenge: At a glance 2009. Atlanta: National Center for Chronic Disease Prevention and Health Promotion.

9. Chandra, S. (2007). Medieval India: From Sultanat to the Mughals- Mughal Empire (1526-1748) (Vol. 2). New Delhi, India: Har Anand Publications.

10. Chatterjee, S. (2015). The Ancient Craft of Dhokra: A case study at Bikna and Dariapur in West Bengal. International Research Journal of Interdisciplinary \& Multidisciplinary Studies (IRJIMS), Volume-I, Issue-IV, 19-23.

11. Cooksey, D. (2016). Understanding the Global Positioning System (GPS). Retrieved July 12, 2016, from MSU GPS Laboratory, Department of Land Resources and Environmental Sciences, Montana State University-Bozeman: http://www.montana.edu/gps/understd.html

12. Council of Handicrafts Development Corporations, Ministry of Textiles, Government of India. (n.d.). FLEXIBLE FISH-BRASS AND WOOD. Retrieved June 27, 2016, from http://www.cohands.in/handmadepages/pdf/204.pdf

13. Council of Handicrafts Development Corporations, Ministry of Textiles, Government of India. (n.d.). Ganjam. Retrieved June 27, 2016, from http://www.cohands.in/handmadepages/pdf/202.pdf

14. Craft and Artisans. (2010). Dhokra Metal Casting of Orissa. Retrieved June 27, 2016, from http://www.craftandartisans.com/dhokra-metal-casting-of-orissa.html

15. Craftmark. (2016). About Us: About Craftmark. Retrieved June 27, 2016, from http://www.craftmark.org/about-us

16. Craftmark: Hand Made in India. (2014). DHOKRA. Retrieved December 18, 2014, from http://www.craftmark.org/sites/default/files/Po17\%2oDhokra.pdf

17. Crafts Council of India. (2014). Flexible Fish Brass \& Wood. Retrieved December 18, 2014, from You are here:Home / Indian Crafts Map / Andhra Pradesh / Flexible Fish Brass \& Wood: http://www.craftscouncilofindia.org/craft-process/flexible-fish-brass-wood/

18. CustomPartNet. (2009). Sheet Metal Gauge Size Chart. Retrieved August 09, 2016, from http://www.custompartnet.com/sheet-metal-gauge 
19. Davis, D. E. (1999). Exploring Your Neighborhood and Your World with a Geographic Information, Volume-1. U.S.A.: ESRI, Inc.

20. dictionary.com. (2016). document. Retrieved May 21, 2016, from http://www.dictionary.com/browse/document

21. Directorate of Handicraft and Cottage Industries, Government of Odisha. (2015). Handicraft $\mathcal{E}$ Cottage Industries, Ganjam. Retrieved December 04, 2104, from http://ganjam.nic.in/industry/handi_cottage_industries.htm

22. foxycart! (2016). Real, Tangible Products. Retrieved June 24, 2016, from Features: http://www.foxycart.com/features/feature/products/physical-products

23. Government of Odisha. (2009). BRIEF HISTORY OF ORISSA. ORISSA REFERENCE ANNUAL, 3536.

24. Halvorsen, T. (2011, January 10). Why Documentation Is Important. Retrieved May 21, 2016, from https://www.fastspot.com/publications/why-documentation-is-important/

25. iceskatingresources.org. (2016). The Learning Process. Retrieved May 30, 2016, from The Learning Process hosted by San Diego Figure Skating Communications a non-profit educational organization SDFSC-Enews.Org: http://iceskatingresources.org/ProcessOfSystematicLearning.html

26. India News. (2015, November 28). Fish Tales Etched in Brass. Retrieved October 11, 2016, from http://huntnews.in/p/detail/ofbief400o7a9985315f6d76949d2ef3?xlang=en\&uc_param_str=dnfrpfbi vesscpgimibtbmntnijblauputoggdnw

27. Jha, S. K. (2016, July 14). Heritage Craft in Crisis: a Case Study of Flexible Brass Craft of Bellaguntha, Ganjam District of Odisha. Chitrolekha International Magazine on Art and Design, 6(2), 20-34.

28. Lorenzen, K. (1996). The relationship between body weight and natural mortality in juvenile and adult fish: a comparison of natural ecosystems and aquaculture. Journal of Fish Biology, Volume 49(4), 627-642.

29. M. Sfakiotakis, D. L. (1999, April 02). Review of fish swimming modes for aquatic locomotion. IEEE Journal of Oceanic Engineering, 24(2), 237-252.

30. Maharana, P. K. (2015, November 18). History of Flexible Brass Craft of Bellaguntha. (S. K. Jha, Interviewer) Ganjam, Odisha, India: Unpublished.

31. Mill, J. (2010). The History of British India: Vol-2 (2010 ed., Vol. 02). New Delhi, India: Cambridge University Press.

32. Minhat, N. H. (2010). Investigation of Brass Microstructure and Mechanical Properties Using Metal Casting. Pahang, Malaysia: Universiti Malaysia Pahang.

33. Mohanty, P. C. (2010). Handicrafts: The Visible Cultural Symbol of Ganjam District. Orissa Review, 42.

34. Moharana, P. K. (2015, November 24). History of Flexible Brass Craft of Bellaguntha. (S. K. Jha, Interviewer)

35. Nathalie Bonnardel, F. Z. (2010, November). The Impact of Technology on Creativity in Design: An Enhancement? CREATIVITY AND INNOVATION MANAGEMENT, 19(2), 180-191.

36. National Council Of Educational Research And Training-NCERT. (2015, January 12). THE MUGHAL EMPIRE. Retrieved January 16, 2016, from http://www.ncert.nic.in/ncerts/l/gessio4.pdf

37. National Institute for Entrepreneurship and Small Business Development. (2016). Home. Retrieved September 03, 2016, from http://niesbud.nic.in/docs/entrepreneurship-and-gender-development-3sep.pdf 
38. Oguamanam, C. (2009). Documentation and Digitization of Traditional Knowledge and Intangible Cultural Knowledge: Challenges and Prospects. Intangible Cultural Heritage and Intellectual Property: Cultural Diversity and Sustainable Development (Antwerp: Intersentia, 2009), 357-383.

39. Priya Ranjan Mahalik, D. R. (2010). Documenting Indigenous Traditional Knowledge in Odisha. Orissa Review, 99-103.

40. S. S. Panwalkar, W. I. (1977). A Survey of Scheduling Rules. Operations Research, Vol-25, Issue-1, 4561.

41. Sahu, D. (2015, November 28). Fish Tales Etched in Brass. Retrieved February 21, 2016, from The New Indian Express: http://www.newindianexpress.com/magazine/2015/nov/28/Fish-Tales-Etchedin-Brass-849508.html

42. Simon Dalby, F. M. (June 1997). Reconceptualising local community: environment, identity and threat. AREA: Royal Geographical Society Journal, Volume 29, Issue 2, 99-108.

43. SocialPedia: WikiPedia of Social Issues. (2016, June 23). Fish Tales Etched in Brass. Retrieved July 21, 2016, from http://www.socialpedia.in/socialwiki/arts-and-crafts/handicrafts/fish-tales-etched-inbrass.html

44. Staff Reporter, The Hindu. (2006, December 21). A kaleidoscope of crafts. Retrieved May 30, 2016, from The Hindu: http://www.thehindu.com/todays-paper/tp-national/tp-andhrapradesh/akaleidoscope-of-crafts/articlezo3665o.ece

45. Suman, S. K. (2015, April 04). Concept and Historical Background of Evidence. ACADEMIKE: Lawctopus' Law Journal + Knowledge Center, Nil.

46. Tango International. (2009). Sustainability of rural development projects. International Fund for Agricultural Development. Rome, Italy: The International Fund for Agricultural Development.

47. The Biomimicry Institute. (2008-2016). WHAT'S BIOMIMICRY? Retrieved August 13, 2016, from Ask Nature: http://www.asknature.org/article/view/why_asknature

48. VedicTime.com. (2012-2016). LIBRARY: The 5th lunar day. Retrieved October 21, 2016, from http://vedictime.com/en/library/panchanga/tithi/panchami

49. Victoria Technical Institute. (1887). About Us. Retrieved October 09, 2016, from VICTORIA TECHNICAL INSTITUTE: http://www.vtichennai.com/VTIProfile.html

50. Vinita. (2010, September 18). ECO-FRIENDLY SOLUTIONS: Cleaning up? Do it the natural way. Retrieved September 06, 2016, from Citizan Matters .in Bangalore: http://bangalore.citizenmatters.in/articles/2362-eco-friendly-cleaning-solutions

51. Wikimedia Foundation, I. (2016, July 12). Brass/History/Early copper zinc alloys. Retrieved July 13, 2016, from https://en.wikipedia.org/wiki/Brass

52. Wikimedia Foundation, Inc. (2016, September 17). Metalsmith. Retrieved October 06, 2016, from https://en.wikipedia.org/wiki/Metalsmith

53. Williams, K. (2016). Queen Victoria: The woman who redefined Britain's monarchy. Retrieved October 20, 2016, from The British Broadcast Corporation-BBC:

http://www.bbc.co.uk/timelines/ztn34j6

Santosh Kumar Jha works as a Senior Faculty and teaches Product and Accessories Design subjects at graduation and post-graduation levels. He is an alumnus of Indian Institute of Crafts and Design-IICD Jaipur and Pondicherry University. Presently he is pursuing Ph.D. degree program from the Utkal University of Culture Bhubaneswar in Cultural Studies discipline, with concentration in the area of Traditional Craft and Product Design under research supervision of Dr. Alekha Charan Sahoo, a well-known Art Historian. 